\title{
Well-Defined Cholesterol Polymers with pH-Controlled Membrane Switching Activity
}

\author{
Sema Sevimli, ${ }^{\dagger, \ddagger, \&}$ Fatih Inci, ${ }^{\dagger, \S}$ Hadi M. Zareie, ${ }^{\|, \perp}$ and Volga Bulmus ${ }^{*, \dagger, \#, \bigcirc}$
}

${ }^{\dagger}$ School of Biotechnology and Biomolecular Sciences, ${ }^{\dagger}$ The Centre for Advanced Macromolecular Design, and ${ }^{\&}$ Australian Centre for Nanomedicine (ACN), The University of New South Wales, Sydney, NSW 2052, Australia

${ }^{\S}$ Department of Molecular Biology-Genetics and Biotechnology Program (MOBGAM), Istanbul Technical University, Istanbul 34469, Turkey

"Department of Electrical-Electronics Engineering and Nanotechnology Graduate Program, Gediz University, Izmir 35665, Turkey

${ }^{\perp}$ Microstructural Analysis Unit, School of Physics and Advanced Materials, University of Technology, Sydney, Altimo NSW 2007, Australia

${ }^{\#}$ Department of Chemical Engineering and ${ }^{\circ}$ Biotechnology and Bioengineering Graduate Program, Izmir Institute of Technology, Urla, Izmir 35430, Turkey

\section{Supporting Information}

ABSTRACT: Cholesterol has been used as an effective component of therapeutic delivery systems because of its ability to cross cellular membranes. Considering this, welldefined copolymers of methacrylic acid and cholesteryl methacrylate, poly(methacrylic acid-co-cholesteryl methacrylate) P(MAA-co-CMA), were generated as potential delivery system components for $\mathrm{pH}$-controlled intracellular delivery of therapeutics. Statistical copolymers with varying cholesterol contents $(2,4$, and $8 \mathrm{~mol} \%)$ were synthesized via reversible addition-fragmentation chain transfer (RAFT) polymerization. Dynamic light scattering (DLS) analysis showed that the hydrodynamic diameters of the copolymers in aqueous solutions ranged from $5 \pm 0.3$ to $7 \pm 0.4 \mathrm{~nm}$ for the copolymers having 2 and $4 \mathrm{~mol} \% \mathrm{CMA}$ and $8 \pm 1.1$ to $13 \pm 1.9 \mathrm{~nm}$ for the copolymer having 8 mol \% CMA with increasing $\mathrm{pH}$ ( $\mathrm{pH} 4.5-7.4)$. Atomic force microscopy (AFM) analysis revealed that the copolymer having 8 mol \% CMA formed supramolecular assemblies while the copolymers having 2 and 4 mol \% CMA existed as unimers in aqueous solution. The $\mathrm{pH}$-responsive behavior of the copolymers was investigated via UV-visible spectroscopy revealing phase transitions at $\mathrm{pH} 3.9$ for 2 mol \% CMA, $\mathrm{pH} 4.7$ for 4 mol \% CMA, and pH 5.4 for 8 mol \% CMA. Lipid bilayers and liposomes as models for cellular membranes were generated to probe their interactions with the synthesized copolymers. The interactions were determined in a $\mathrm{pH}$-dependent manner (at $\mathrm{pH} 5.0$ and 7.4) using surface plasmon resonance (SPR) spectroscopy and liposome leakage assay. Both the SPR analyses and liposome leakage assays indicated that the copolymer containing 2 mol \% CMA displayed the greatest polymer-lipid interactions at $\mathrm{pH}$ 5.0, presenting the highest binding ability to the lipid bilayer surfaces, and also demonstrating the highest membrane destabilization activity. CellTiter-Blue assay showed that the copolymers did not affect the cell viability up to $30 \mu \mathrm{M}$ over a period of $72 \mathrm{~h}$.

\section{INTRODUCTION}

A number of potent therapeutic strategies rely on effective transport of macromolecular therapeutics, such as proteins/ peptides and DNA/RNA, into cells. However, most macromolecular therapeutics cannot diffuse passively through cellular membranes because of their large hydrodynamic size and hydrophilic nature. ${ }^{1-6}$ Various systems such as lipids, ${ }^{7-9}$ endosome-fusogenic peptides, ${ }^{10-13}$ and endosome-lytic polymers ${ }^{14-26}$ have been developed to increase the intracellular transport of macromolecular therapeutics.

$\mathrm{pH}$-responsive membrane-destabilizing polymers have improved the intracellular delivery of therapeutics both in vitro $^{27-29}$ and in vivo. ${ }^{30}$ These polymers that mimic the $\mathrm{pH}$ controllable membrane activity of endosome-fusogenic peptides combine hydrophobic and acidic units in their structure and display a transition from a hydrophilic state to a lipophilic state at acidic pHs, enhancing interactions with cell membrane. Poly(methacrylic acid), a $\mathrm{pH}$-responsive polymer, has been widely utilized as an essential constituent for generating $\mathrm{pH}$ sensitive therapeutic delivery systems. ${ }^{31-34}$

When compared with peptides and synthetic polymers, lipidbased systems have been more effective in interacting with cellular membranes and enhancing the cytoplasmic delivery of therapeutics. The naturally occurring hydrophobic building blocks ${ }^{35}$ are essential for enhancing stability, ${ }^{36}$ stimulating selfassembly, ${ }^{37,38}$ increasing cellular uptake via endocytosis mechanisms, ${ }^{39}$ disrupting endosomal membranes along with facilitating effective transfection of macromolecular therapeu-

Received: May 31, 2012

Revised: August 23, 2012

Published: August 24, 2012 
Table 1. Experimental Conditions for Copolymerization of t-BMA and CMA ${ }^{a}$

\begin{tabular}{|c|c|c|c|c|c|c|}
\hline total monomer concentration $(\mathrm{M})$ & {$[\mathrm{t}-\mathrm{BMA}] /[\mathrm{CMA}] /[\mathrm{RAFT}] /[\mathrm{AIBN}]$ (mole ratio) } & time $(\mathrm{h})$ & conversion $^{b}(\%)$ & $M_{\mathrm{n}}^{c}(\mathrm{~g} / \mathrm{mol})$ & $\mathrm{PDI}^{d}$ & $M_{\mathrm{n}, \text { theo }}{ }^{e}$ \\
\hline 1.25 & $40.0 / 10.0 / 1.0 / 0.2$ & 20 & 74 & 4000 & 1.13 & 4200 \\
\hline 4.08 & $200.0 / 4.0 / 1.0 / 0.2$ & 6 & 48 & 9600 & 1.10 & 14500 \\
\hline 4.08 & $200.0 / 4.0 / 1.0 / 0.2$ & 9 & 60 & 11900 & 1.14 & 18150 \\
\hline 8.20 & $200.0 / 5.0 / 1.0 / 0.2$ & 6 & 56 & 10500 & 1.14 & 16900 \\
\hline 8.20 & $200.0 / 5.0 / 1.0 / 0.2$ & 9 & 64 & 14000 & 1.12 & 19200 \\
\hline
\end{tabular}

${ }^{a}$ Polymerization conditions: temperature $=68{ }^{\circ} \mathrm{C}$, solvent $=$ toluene. ${ }^{b}$ Monomer conversion determined by ${ }^{1} \mathrm{H}$ NMR. ${ }^{c}$ The number average molecular weight determined by THF GPC analysis is using PS standards. ${ }^{d}$ Polydispersity index. ${ }^{e}$ The theoretical molecular weight calculated by $M_{\mathrm{n}, \text { theo }}=\left([\mathrm{M}]_{\mathrm{o}} /[\mathrm{RAFT}]_{\mathrm{o}}\right) \times$ conversion $\times \mathrm{MW}_{\text {monomer, }}$, where $[\mathrm{M}]_{\mathrm{o}},[\mathrm{RAFT}]_{\mathrm{o}}$, conversion, $\mathrm{MW}_{\text {monomer }}$ are the initial monomer and RAFT agent concentrations, monomer conversion, and molecular weight of the monomer, respectively.

tics, ${ }^{8,4041}$ and generating carriers which are well tolerated in biological systems. ${ }^{42}$ For example, cholesterol, which accounts for $20-25 \%$ of the lipid molecules in the cell membrane, ${ }^{43}$ interacts easily with the cell membrane. It is easily transported into the cells by lipoproteins and albumin, usually via endocytosis mechanism. In a number of studies, ${ }^{8,41}$ cholesterol conjugation has proved to facilitate the entry of macromolecular therapeutics into the cells.

Considering the ability of cholesterol to cross cellular membranes, we prepared well-defined copolymers of methacrylic acid and cholesteryl methacrylate, poly(methacrylic acidco-cholesteryl methacrylate) $\mathrm{P}\left(\mathrm{MAA}-\mathrm{co}^{-\mathrm{CMA}}\right.$ ), as potential components of delivery systems for $\mathrm{pH}$-controlled delivery of therapeutics into cells. Hence, the ability of cholesterol to interact with lipid membranes was potentially synergized with multiplicity and $\mathrm{pH}$-sensitivity in a copolymer structure. The reversible addition-fragmentation chain transfer (RAFT) polymerization $^{44-48}$ was used to synthesize well-defined copolymers with controlled molecular weight and narrow molecular weight distribution. Aqueous solution properties of the copolymers were investigated by varying techniques revealing information on hydrodynamic size, conformation, and phase transition as a function of $\mathrm{pH}$. The $\mathrm{pH}$-dependent membrane-destabilizing activities of copolymers were examined by the liposome leakage assay and further lipid layer interactions were explored by surface plasmon resonance (SPR) spectroscopy. Furthermore, the cytotoxicity of copolymers with varying cholesterol content was investigated using a human neuroblastoma cell line. Overall, the results support the value of these new copolymers for further investigations as components of delivery systems for transporting therapeutics through cellular membranes.

\section{EXPERIMENTAL SECTION}

Materials. The initiator, 2,2-azobisisobutyronitrile (AIBN), was recrystallized twice from methanol prior to use. High purity nitrogen (Linde gases, 99.99\%) was used for removing oxygen from the polymerization solutions. tert-Butyl methacrylate (t-BMA) monomer (Aldrich, 99\%) was purified via basic alumina gel column chromatography before use. Triethylamine (Sigma-Aldrich, 99\%) was stored with sodium hydroxide pellets (Univar) for 2 days prior to use. Cholesterol (Sigma, 98\%), methacryloyl chloride (Fluka, $>97 \%$ ), dichloromethane (Univar, analytical grade reagent), toluene (Univar, analytical grade reagent), methanol (Univar, analytical grade reagent), acetone (Univar, analytical grade), trifluoro acetic acid (Sigma), Triton X100 (Sigma), phosphate buffer saline (PBS) pellets (Sigma), potassium dihydrogen phosphate (Univar), sulforhodamine B (Sigma), egg yolk phosphatidylcholine (Sigma), chloroform (Sigma), hexadecanethiol (Sigma), Dulbecco's modified Eagle medium (DMEM; Lonza), 10\% Australian fetal bovine serum (FBS; Lonza), and CellTiter-Blue cell viability assay (Promega) were used as received. Cholesteryl methacrylate (CMA) monomer was synthesized according to a modified procedure described previously in the literature (Figure S1, Supporting Information). ${ }^{49,50}$ The RAFT agent, 4-(cyanopentanoic acid)-4-dithiobenzoate (CPADB), was synthesized according to the procedure reported in the literature. ${ }^{51,52}$ Membranes for dialysis (MWCO 3500) were purchased from Fisher Biotech (Cellu SepT4, regenerated cellulose-Tubular membrane).

Analytical Techniques. Nuclear Magnetic Resonance (NMR) Spectroscopy. All NMR spectra were taken using Bruker $300 \mathrm{MHz}$ NMR spectrometer. According to their solubility, samples were analyzed in $\mathrm{CDCl}_{3}, \mathrm{DMSO}-d_{6}$, or $\mathrm{D}_{2} \mathrm{O}$ as the NMR solvents.

Gel Permeation Chromatography (GPC). Gel permeation chromatography was performed using HPLC grade tetrahydrofuran (THF) as the mobile phase. Polymer solutions $(3-5 \mathrm{mg} / \mathrm{mL}$ in THF) were injected to GPC at $40{ }^{\circ} \mathrm{C}$ (flow rate $=1 \mathrm{~mL} / \mathrm{min}$ ). A Shimadzu modular system comprising of a SIL-10AD autoinjector, a PL $5.0 \mathrm{~mm}$ bead-size guard column $(50 \times 7.8 \mathrm{~mm})$ followed by four linear PL (Styragel) columns $\left(10^{5}, 10^{4}, 10^{3}\right.$, and $500 \AA$ ) and a RID-10A differential refractive-index detector was used. Calibration was performed with commercial polystyrene standards ranging from 500 to $10^{6} \mathrm{~g} / \mathrm{mol}$.

UV-Visible (UV-vis) Spectrophotometer. UV-visible spectra were obtained by a double beam Hitachi-UV spectrometer (Model No.: U2800) using UV solutions 2.1 software. The absorbance of polymer solutions $(0.125 \mathrm{mM})$ in buffer solutions with varying $\mathrm{pH}$ values was measured at $400 \mathrm{~nm}$ using quartz cuvettes.

Differential Scanning Calorimeter (DSC). DSC analysis was performed using a Perkin-Elmer Pyris 1 under $\mathrm{N}_{2}$ atmosphere, from -10 to $250{ }^{\circ} \mathrm{C}$ at a heating rate of $15^{\circ} \mathrm{C} / \mathrm{min}$. High purity indium was used to calibrate the calorimeter. Thermal history difference was erased by reheating the sample and recording a second DSC scan; 10$15 \mathrm{mg}$ polymer was used for each running.

Dynamic Light Scattering (DLS). Dynamic light scattering studies were performed using a Malvern Zetasizer NaNo ZS Instrument (Malvern, U.S.A.) equipped with a $4 \mathrm{mV} \mathrm{He}-\mathrm{Ne}$ laser operating at $\lambda=$ $633 \mathrm{~nm}$, an avalanche photodiode detector with high quantum efficiency, and an ALV/LSE-5003 multiple tau digital correlator electronics system. The polymer sample solutions were prepared at $0.125 \mathrm{mM}$ concentration.

Atomic Force Microscopy (AFM). Atomic force microscopy (AFM) studies were performed using a Nanomagnetic AFM apparatus in tapping mode. A total of $20 \mu \mathrm{L}$ of the copolymer solution $(0.125 \mathrm{mM})$ at $\mathrm{pH} 5.0$ was placed on silicon substrate, and the sample was dried under atmospheric conditions at room temperature. The scans were typically done at rates between 1 and $4 \mathrm{~Hz}$. The images were obtained using a silicon nitride cantilever with a nominal force constant of 0.38 $\mathrm{N} / \mathrm{m}$.

fMax Fluorescence Spectroscopy. A fMax Fluorescence Plate Reader from fMax Fluorescence Microplate Molecular Devices Corporation was used for measurements in Liposome Lysis Assay and CellTiter-Blue Assay with fluorescence readings measured at $488_{\lambda_{\mathrm{ex}}} / 585_{\lambda_{\mathrm{em}}} \mathrm{nm}$ and $540_{\lambda_{\mathrm{ex}}} / 590_{\lambda_{\mathrm{em}}} \mathrm{nm}$, respectively. Measurements were performed by using the fMax Fluorescence user software program.

Methods. The procedure for the RAFT homopolymerizations of cholesteryl methacrylate (CMA) and tert-butyl methacrylate (t-BMA) 
was described in Supporting Information (Schemes S1 and S2 and Figures S2 and S3).

RAFT Copolymerization of tert-Butyl Methacrylate (t-BMA) and Cholesteryl Methacrylate (CMA). The copolymerizations were conducted at varying comonomer concentrations as shown in Table 1. t-BMA and CMA monomers, initiator (2,2-azobisisobutyronitrile (AIBN)), and RAFT agent (4-(cyanopentanoic acid)-4-dithiobenzoate $(\mathrm{CPADB}))$ were dissolved in toluene. The solution was sealed with a rubber septum and then degassed using nitrogen for $30 \mathrm{~min}$ in an ice bath. The polymerization was carried out by immersing the vial into a preheated oil bath of $68{ }^{\circ} \mathrm{C}$. At predetermined time intervals polymerization solution was drawn out from the vial using a syringe for further analysis. The monomer conversion was determined by ${ }^{1} \mathrm{H}$ NMR analysis of the crude polymerization mixtures. The polymer sample was purified by precipitation twice in methanol and dried under vacuo overnight. ${ }^{1} \mathrm{H}$ NMR spectrum of the purified product is shown in Supporting Information (Figure S7A). ${ }^{1} \mathrm{H}$ NMR $\left(\mathrm{CDCl}_{3}, 300\right.$ $\mathrm{MHz})$ ppm: $5.3(\mathrm{~d}, 1 \mathrm{H},-\mathrm{C}=\mathrm{CH}$-, olefin group in cholesterol), $4.5(\mathrm{~m}$, $\left.1 \mathrm{H},-\mathrm{COO}-\mathrm{CH}-), 2.3\left(\mathrm{~d}, 2 \mathrm{H},-\mathrm{CH}-\mathrm{CH}_{2}\right)^{-}\right), 1.81\left(\mathrm{~s}, 2 \mathrm{H},-\mathrm{C}-\mathrm{CH}_{2}-\right), 1.41$ (s, $\left.9 \mathrm{H},-\mathrm{C}-\left(\mathrm{CH}_{3}\right)_{3}\right), 1.02\left(\mathrm{~s}, 3 \mathrm{H},-\mathrm{C}-\mathrm{CH}_{3}\right), 0.93\left(\mathrm{~d}, 3 \mathrm{H},-\mathrm{CH}-\mathrm{CH}_{3}\right)$, $0.88-0.84\left(\mathrm{q}, 6 \mathrm{H},-\mathrm{CH}-\left(\mathrm{CH}_{3}\right)_{2}\right), 0.68\left(\mathrm{~s}, 3 \mathrm{H},-\mathrm{C}-\mathrm{CH}_{3}\right)$. The molecular weight of the purified polymers was obtained by gel permeation chromatography (GPC) using THF as the mobile phase.

Hydrolysis of Poly(tert-butyl methacrylate-co-cholesteryl methacrylate) to Poly (methacrylic acid-co-cholesteryl methacrylate).

The copolymer P(t-BMA-co-CMA) (325 mg, $2.3 \mathrm{mmol}$ tert-butyl ester) was dissolved in dichloromethane (DCM; $5 \mathrm{~mL}$ ). The mixture was allowed to stir for $10 \mathrm{~min}$ to dissolve the polymer. Trifluoro acetic acid (TFA; $0.894 \mathrm{~mL}, 114 \mathrm{mmol}$ ) was slowly added while vigorously stirring. The reaction continued to stir for $32 \mathrm{~h}$ at room temperature. Excess TFA along with DCM was removed at room temperature with air flowing through the vial and dried under vacuum overnight. Removal of tert-butyl group from the copolymer was verified by ${ }^{1} \mathrm{H}$ NMR

${ }^{1} \mathrm{H}$ NMR (DMSO, $300 \mathrm{MHz}$ ) ppm: 12.3 (s, 1H, -CO-OH) 5.3 (d, $1 \mathrm{H},-\mathrm{C}=\mathrm{CH}$-, olefin group in cholesterol), $4.5(\mathrm{~m}, 1 \mathrm{H},-\mathrm{COO}-\mathrm{CH}-)$, $\left.2.3\left(\mathrm{~d}, 2 \mathrm{H},-\mathrm{CH}-\mathrm{CH}_{2}\right)^{-}\right), 1.82\left(\mathrm{~s}, 2 \mathrm{H},-\mathrm{C}-\mathrm{CH}_{2}{ }^{-}\right), 1.02\left(\mathrm{~s}, 3 \mathrm{H},-\mathrm{C}-\mathrm{CH}_{3}\right)$, $0.93\left(\mathrm{~d}, 3 \mathrm{H},-\mathrm{CH}-\underline{\mathrm{CH}}_{3}\right), 0.88-0.84\left(\mathrm{q}, 6 \mathrm{H},-\mathrm{CH}-\left(\underline{\mathrm{CH}}_{3}\right)_{2}\right), 0.68(\mathrm{~s}, 3 \mathrm{H}$, $\left.-\mathrm{C}-\mathrm{CH}_{3}\right)$.

To obtain the final product, the copolymer, poly(methacrylic acidco-cholesteryl methacrylate) $\mathrm{P}$ (MAA-co-CMA), was dissolved in basic aqueous solution $(10 \mathrm{mM} \mathrm{NaOH}$ solution prepared with deionized water) and transferred to dialysis tubing (MWCO: 3500). The solution was dialyzed against deionized water for 3 days followed by freeze-drying giving a white powder. The average yield was $90 \%$ for overall hydrolysis process. The final polymer was analyzed by ${ }^{1} \mathrm{H}$ NMR (Figure S7B, Supporting Information).

${ }^{1} \mathrm{H}$ NMR $\left(\mathrm{D}_{2} \mathrm{O}, 300 \mathrm{MHz}\right)$ ppm: $5.3(\mathrm{~d}, 1 \mathrm{H},-\mathrm{C}=\underline{\mathrm{CH}}-$, olefin group in cholesterol), 4.5 (m, $1 \mathrm{H},-\mathrm{COO}-\mathrm{CH}-), 1.81\left(\mathrm{~s}, 2 \mathrm{H},-\mathrm{C}-\mathrm{CH}_{2}-\right.$ ), $1.02\left(\mathrm{~s}, 3 \mathrm{H},-\mathrm{C}-\mathrm{CH}_{2}\right), 0.68\left(\mathrm{~s}, 3 \mathrm{H},-\mathrm{C}-\mathrm{CH}_{3}\right)$.

Turbidity Assay. The $\mathrm{pH}$-responsive phase behaviors of polymers were studied by measuring the turbidity change of polymer solutions at varying $\mathrm{pH}$ values via UV-visible spectroscopy. ${ }^{53}$ For spectrophotometric analysis, citrate buffer solutions in the $\mathrm{pH}$ range of 3.0-7.0 were prepared by mixing citric acid $(0.1 \mathrm{M})$ and dibasic sodium phosphate $(0.2 \mathrm{M})$ aqueous solutions. A phosphate buffer solution $(0.1 \mathrm{M})$ at $\mathrm{pH} 7.4$ was prepared by mixing sodium phosphate monobasic $(0.1 \mathrm{M})$ and sodium phosphate dibasic $(0.1 \mathrm{M})$ aqueous solutions. The ionic strength of the buffer solutions were adjusted to $0.1 \mathrm{M}$ by the addition of $\mathrm{NaCl}$ to yield isotonic solutions. Three different $\mathrm{P}$ (MAA-co-CMA) samples with varying cholesterol content, ( 2 mol \% CMA, with number average molecular weight $\left(M_{\mathrm{n}}\right)_{\mathrm{GPC}}$ of $16500 \mathrm{~g} / \mathrm{mol}$ and polydispersity index (PDI) of $1.19 ; 4 \mathrm{~mol} \% \mathrm{CMA}$, with $\left(M_{\mathrm{n}}\right)_{\mathrm{GPC}} 15800 \mathrm{~g} / \mathrm{mol}$ and PDI $1.10 ; 8 \mathrm{~mol} \% \mathrm{CMA}$, with $\left(M_{\mathrm{n}}\right)_{\mathrm{GPC}} 18000 \mathrm{~g} / \mathrm{mol}$ and PDI 1.11) were dissolved in buffer solutions. The final copolymer concentration was $0.125 \mathrm{mM}$. The absorbance of each polymer solution from acidic $\mathrm{pH}$ to neutral $\mathrm{pH}$ was detected by a UV-visible spectrophotometer at $400 \mathrm{~nm}$.

Surface Plasmon Resonance. Surface plasmon resonance (SPR) experiments were performed using a Biacore 2000 system (GE
Healthcare Biacore) to monitor polymer binding onto lipid bilayers in real-time. SPR gold slides, used for lipid bilayer immobilization, were first washed with ethanol, treated with $0.1 \mathrm{mM}$ hexadecanethiol/DCM solution overnight (to produce self-assembled monolayer of hexadecanethiol), then rinsed thoroughly with DCM, and finally dried under a gentle stream of nitrogen.

Liposomes of different compositions were prepared to mimic both the cell plasma membrane (composed of cholesterol/phosphatidylcholine constituents at a cholesterol/phosphatidylcholine molar ratio of 0.42 ) and endosome membrane (molar ratio of 0.80 ) lipid arrangements. ${ }^{54}$ Small, unilamellar vesicles (SUV) were prepared by sonication, according to the protocol described by Morrissey Laboratories. ${ }^{55}$ In brief, egg yolk phosphatidylcholine $(8.4 \mathrm{mg}, 0.01$ mmol for plasma membrane; $7 \mathrm{mg}, 0.08 \mathrm{mmol}$ for endosome membrane) and cholesterol (1.6 $\mathrm{mg}, 0.04 \mathrm{mmol}$ for plasma membrane; $3 \mathrm{mg}, 0.07 \mathrm{mmol}$ for endosome) were solubilized in 1 $\mathrm{mL}$ of chloroform (in a round-bottom flask) and dried under nitrogen, generating a lipid film that was stored overnight at $+4{ }^{\circ} \mathrm{C}$. The thin lipid film was resuspended in $5 \mathrm{~mL}$ phosphate buffered $(\mathrm{pH} 7.4)$ or citrate-phosphate buffer ( $\mathrm{pH}$ 5.0) by vortex mixing, hydrated for $1 \mathrm{~h}$ at room temperature and then sonicated forming SUVs.

Liposomes were injected to the SPR at $20 \mu \mathrm{L} / \mathrm{min}$ for $6.5 \mathrm{~min}$ until the surfaces were saturated. The solution was allowed to sit on the surface for $20 \mathrm{~min}$. During this period, liposomes were attached to selfassembled hexadecane monolayer surface and then disrupted to form lipid bilayer on the surface. Surfaces covered with lipid bilayer were then washed with several pulses (ranging from $30 \mathrm{~s}$ to $5 \mathrm{~min}$ ) of related buffer (citrate-phosphate buffer at $\mathrm{pH} 5.0$ or phosphate buffer at $\mathrm{pH}$ 7.4) to remove loosely bound lipids and stabilize the surfaces. Polymer solutions $\left(2 \mathrm{~mol} \% \mathrm{CMA}\right.$, with $\left(M_{\mathrm{n}}\right)_{\mathrm{GPC}}$ of $16500 \mathrm{~g} / \mathrm{mol} ; 4$ mol \% CMA with $\left(M_{\mathrm{n}}\right)_{\mathrm{GPC}} 15800 \mathrm{~g} / \mathrm{mol} ; 8 \mathrm{~mol} \%$ CMA with $\left(M_{\mathrm{n}}\right)_{\mathrm{GPC}}$ $18000 \mathrm{~g} / \mathrm{mol}$ ) prepared at $0.5 \mathrm{mM}$ concentration in related buffer solutions (citrate-phosphate buffer at $\mathrm{pH} 5.0$ or phosphate buffer at $\mathrm{pH}$ 7.4) were injected over the surfaces at $20 \mu \mathrm{L} / \mathrm{min}$ flow rate, allowing real-time monitoring of the interactions between polymers and lipid bilayers of different composition in acidic and neutral medium. Lipid bilayer surfaces that reached saturation point were rinsed with $6.5 \mathrm{~min}$ injections of their related buffer solutions.

Liposome Leakage Assay. Liposomes composed of cholesterol/ phosphatidylcholine constituents at a cholesterol/phosphatidylcholine molar ratio of 0.42 were prepared intending to mimic the cell plasma membrane lipid composition. ${ }^{54}$ The liposomes were prepared by sonication according to a protocol described by Morrissey Laboratories. ${ }^{55}$ Briefly, egg yolk phophatidylcholine $(42 \mathrm{mg}, 0.05$ $\mathrm{mmol})$ and cholesterol $(8 \mathrm{mg}, 0.02 \mathrm{mmol})$ were dissolved in $1 \mathrm{~mL}$ chloroform and placed in a round-bottom flask. A thin lipid film was generated on the bottom of the flask by evaporation of the chlorofom via nitrogen gas and stored overnight at $+4{ }^{\circ} \mathrm{C}$. The lipid film was hydrated with sulforhodamine B (SRB; $2.5 \mathrm{mM}, 2.5 \mathrm{~mL}$ ) solution in phosphate buffer saline ( $\mathrm{pH} 7.4$ ) and then vortexed vigorously. The lipid solution was incubated for $1 \mathrm{~h}$ at room temperature followed by sonication generating small, unilamellar vesicles (SUV) with diameters in the range of 15-50 nm. Untrapped SRB molecules were eliminated by size exclusion chromatography on a Sephadex G-25 column (bed volume $8.3 \mathrm{~mL}$, bed height $5 \mathrm{~cm}$; PD-10) using phosphate buffer saline as the eluting solution. $750 \mu \mathrm{L}$ of the SRB loaded liposomes were added to the isotonic buffer solution $(3.75 \mathrm{~mL}$, citrate-phosphate buffer at $\mathrm{pH} 5.0$ or phosphate buffer at $\mathrm{pH} 7.4)$. The solution was equally divided into 6 vials $(750 \mu \mathrm{L})$ and the final volume was made up to $900 \mu \mathrm{L}$ by addition of isotonic buffer solution (in the absence of polymer), Triton X-100 solution ( $10 \%$ in Milli-Q water) or copolymer solution prepared in Milli- $\mathrm{Q}$ water at $1.5 \mu \mathrm{M}$ or $3.0 \mu \mathrm{M}$ concentration ( 2 mol \% CMA, with $\left(M_{\mathrm{n}}\right)_{\mathrm{GPC}}$ of $16500 \mathrm{~g} / \mathrm{mol} ; 4 \mathrm{~mol} \%$ CMA with $\left(M_{\mathrm{n}}\right)_{\mathrm{GPC}} 15800 \mathrm{~g} / \mathrm{mol} ; 8 \mathrm{~mol} \%$ CMA with $\left(M_{\mathrm{n}}\right)_{\mathrm{GPC}} 18000 \mathrm{~g} / \mathrm{mol}$ or poly(methacrylic acid), PMAA, cholesterol mole content $0 \%$ with $\left.\left(M_{\mathrm{n}}\right)_{\mathrm{GPC}} 36000 \mathrm{~g} / \mathrm{mol}\right)$. The reason for using dilute copolymer solutions were to determine the effectiveness of the copolymers in selective ( $\mathrm{pH}$-dependent) membrane destabilization, as detailed in Results and Discussion. After $1 \mathrm{~h}$ incubation, the solutions were transferred to a 96-well plate and the fluorescent intensity $\left(\lambda_{\mathrm{ex}}=488\right.$ 
Scheme 1. Synthesis of P(t-BMA-co-CMA) via RAFT Polymerization and Subsequent Acid Hydrolysis, Yielding Poly(methacrylic acid-co-cholesteryl methacrylate) (P(MAA-co-CMA))
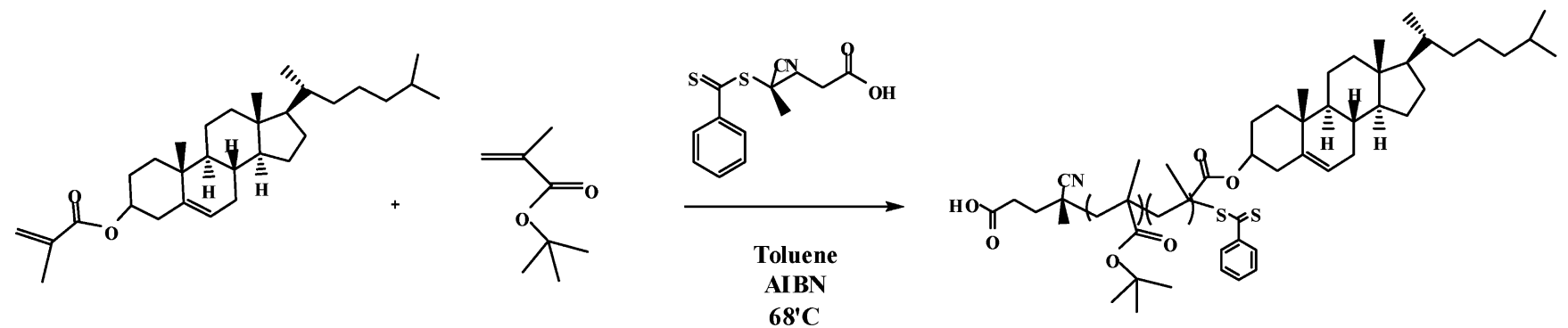

(1)

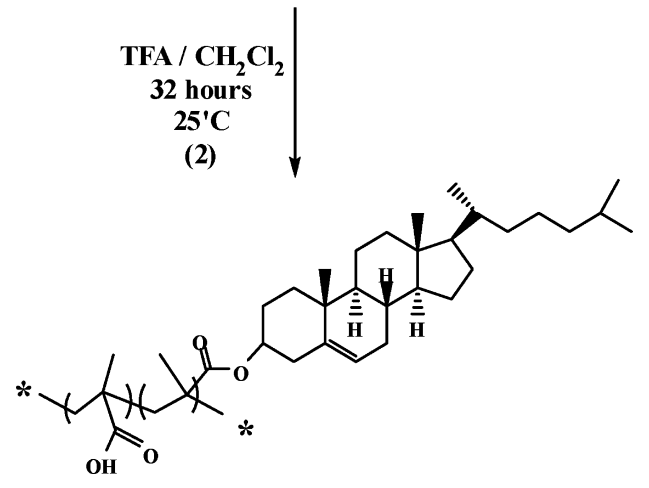

$\left.\mathrm{nm}, \lambda_{\mathrm{em}}=585 \mathrm{~nm}\right)$ of the resulting solutions was measured by a fMax fluorescence plate reader (fMax Fluorescence Microplate Molecular Devices Corporation). In a control experiment, a series of SRB-loaded liposomes were analyzed by the same protocol without using polymer. This experiment suggested that SPR-loaded liposomes, without polymer treatment, were stable in isotonic buffer solutions $(\mathrm{pH} 5.0$ and 7.4) as they showed similar fluorescence trends in both environments. The calibration curves of SRB fluorescence were obtained at both $\mathrm{pH}$ values prior to the liposome leakage experiment. Percent leakage was defined as

$$
\text { \%leakage }=\left(F_{\mathrm{p}}-F_{0}\right) /\left(F_{100}-F_{0}\right) \times 100
$$

where $F_{0}$ and $F_{\mathrm{p}}$ are the fluorescence intensity of blank solution (SRBloaded liposomes in buffer solutions without polymer) and polymer solutions (SRB-loaded liposomes in buffer solutions with polymer), respectively. A $100 \%$ leakage, $F_{100}$, was taken as the fluorescence intensity of the SRB-loaded liposome solutions after the addition of 10\% Triton X-100, which corresponded to a complete liposome lysis.

Determination of Cell Viability via CellTiter-Blue Assay. Human neuroblastoma (SH-EP) cell line was used to determine the toxicity of the polymers. The cells were grown in Dulbecco's modified Eagle medium (DMEM) containing $4.5 \mathrm{~g} / \mathrm{L}$ glucose and L-glutamine, supplemented with $10 \%$ Australian Fetal Bovine Serum (FBS). Cells were grown at $37{ }^{\circ} \mathrm{C}$ in $5 \% \mathrm{CO}_{2}$ and $95 \%$ humidity.

The cytotoxicity of the P(MAA-co-CMA) on SH-EP cells was evaluated using the CellTiter-Blue cell viability assay. The assay was performed according to the manufacturer's protocol. In brief, SH-EP cells were seeded in to 96 -well plates at $3 \times 10^{3}$ cells $/ \mathrm{mL}$ and grown for $24 \mathrm{~h}$ at $37^{\circ} \mathrm{C}, 5 \% \mathrm{CO}_{2}$ in DMEM containing $10 \% \mathrm{FBS}$. Cells were then exposed to varying concentrations of $\mathrm{P}$ (MAA-co-CMA) and incubated for another $72 \mathrm{~h}$. After the incubation period, $20 \mu \mathrm{L}$ of CellTiter-Blue was added to each well, and the plate was further incubated at $37^{\circ} \mathrm{C}, 5 \% \mathrm{CO}_{2}$ for $2-3 \mathrm{~h}$. The fluorescence was recorded at $\lambda_{\text {ex }}=540 \mathrm{~nm}$ and $\lambda_{\text {em }}=590 \mathrm{~nm}$. The effect of the presence of polymer on the viability of the cells was calculated as follows:

$$
\text { \%cell viability }=\left\{\frac{F_{\operatorname{Tr}}-F_{B}}{F_{U n t r}-F_{B}}\right\} \times 100
$$

$F_{\operatorname{Tr}}$ and $F_{\mathrm{Untr}}$ are the fluorescence intensity of treated cells (treatmented with polymer solutions at varying concentrations) and untreated cells (cells only in media, positive control for $100 \%$ viability), respectively. $F_{\mathrm{B}}$, is the fluorescence intensity of blank wells (wells with media and polymer treatment, no cells) where the values are similar to $10 \%$ Triton X-100 treatment, which corresponds to $0 \%$ viability. Samples were tested in triplicate using cells at different passage numbers.

\section{RESULTS AND DISCUSSION}

Copolymerization of tert-Butyl Methacrylate and Cholesteryl Methacrylate. Owing to the solubility mismatch between CMA monomer (water insoluble) and methacrylic acid monomer (water soluble), a two-step reaction route was adopted for polymerization (Scheme 1, step 1). Cholesterol was first esterified forming a methacrylate and then used for copolymerization with $\mathrm{t}-\mathrm{BMA}$ in the presence of CPABD, a dithioester RAFT agent, which has been widely used for the polymerization of methacrylates. ${ }^{56} \mathrm{pH}$-responsive copolymers of CMA were then formed by the hydrolysis of t-BMA units of the copolymers to methacrylic acid units. tert-Butyl ester has received significant attention as an effective protecting group due to the labile ester-alkyl bond. ${ }^{57}$ The tert-butyl protecting group can be easily removed via acid-catalyzed processes such as toluene/toluenesulfonic acid, ${ }^{57,58}$ dioxane $/ \mathrm{HCl}^{59}$ or dichloromethane (DCM)/trifluoroacetic acid (TFA) treatments. ${ }^{60,61}$

GPC traces of P(t-BMA-co-CMA) (obtained at [t-BMA]/ $[\mathrm{CMA}] /[\mathrm{RAFT}] /[\mathrm{AIBN}]$ molar ratio of 200.0/4.0/1.0/0.2, total monomer concentration of $4.08 \mathrm{M}$ ), shown in Figure 1A, reveals the formation of monomodal molecular weight distribution during polymerization. The monomodal GPC chromatograms indicate that the polymerization occurs in the absence of side reactions, which can cause branched polydisperse polymers. ${ }^{62}$ It is evident from GPC traces that the molecular weight of $\mathrm{P}(\mathrm{t}-\mathrm{BMA}-\mathrm{co}-\mathrm{CMA})$ increases with monomer conversion. The semilogarithmic monomer conversion (determined by ${ }^{1} \mathrm{H}$ NMR) shown in Figure $1 \mathrm{~B}$ indicates that monomer conversion increases concomitantly with time. The evolution of the $M_{\mathrm{n}}$ with monomer conversion 
A.

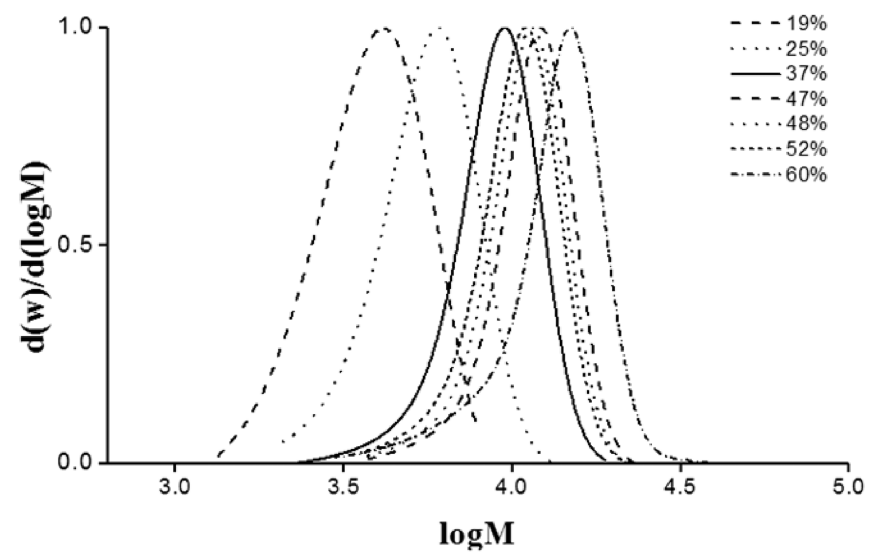

B.

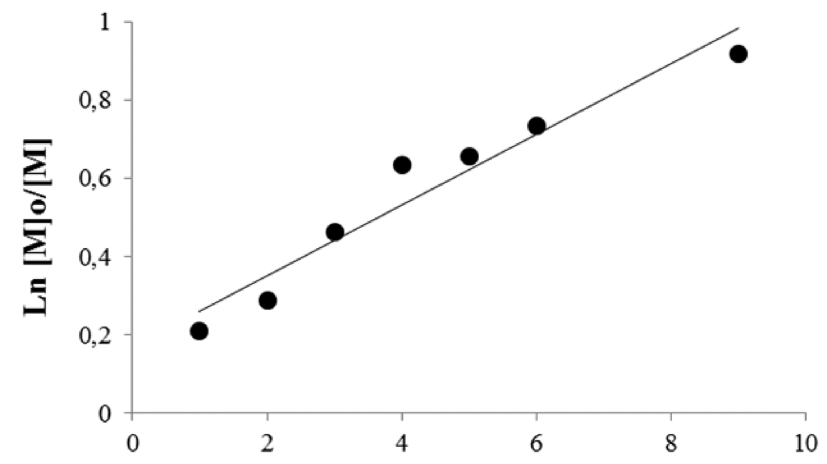

Time (hours)

C.

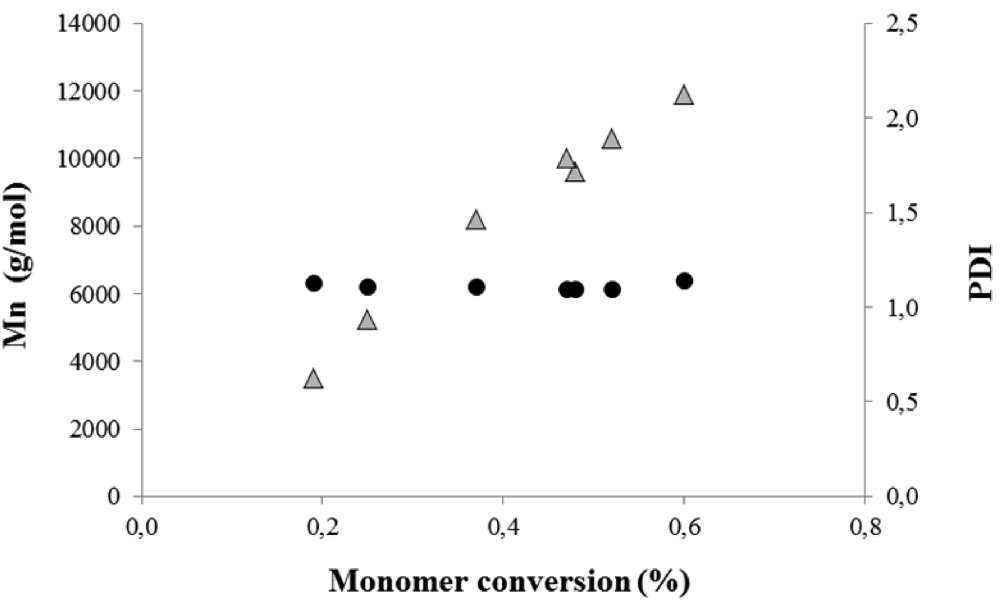

Figure 1. Results of RAFT polymerization of $\mathrm{P}(\mathrm{t}-\mathrm{BMA}-\mathrm{co}-\mathrm{CMA})$ in toluene at $68{ }^{\circ} \mathrm{C}([\mathrm{t}-\mathrm{BMA}] /[\mathrm{CMA}] /[\mathrm{RAFT}] /[\mathrm{AIBN}]=200.0 / 4.0 / 1.0 / 0.2)$. (A) GPC traces of P(t-BMA-co-CMA) synthesized at different polymerization times (from THF GPC); (B) $\operatorname{Ln}[\mathrm{M}]_{\mathrm{o}} /[\mathrm{M}]$ vs time; and (C) number average molecular weight $\left(M_{\mathrm{n}}\right)_{\mathrm{GPC}}$ (triangles) and PDI (circles) vs monomer conversion.

(Figure 1C) reveals a linear pseudo-first-order kinetic plot along with a narrow polydispersity profile of the produced polymers. As a result, both narrow molecular weight distributions and linear increase of molecular weights with monomer conversion indicate that the polymerization of $\mathrm{P}(\mathrm{t}-$ BMA-co-CMA) performed at [t-BMA $] /[\mathrm{CMA}] /[\mathrm{RAFT}] /$ [AIBN] ratio of 200.0/4.0/1.0/0.2 (4.0M/0.08M/0.02M/4 $\mathrm{mM}$ ) was a well-controlled polymerization consistent with the known traits of the RAFT mechanism.

Table 1, which contains polymerization conditions for $\mathrm{P}(\mathrm{t}$ BMA-co-CMA) at varying monomer/RAFT agent ratios, also confirms that the synthesized polymers hold RAFT-controlled character. In summary, increasing the monomer/RAFT agent molar ratio or the polymerization time at a fixed monomer/ RAFT agent molar ratio result in larger molecular weight polymers, proving that polymerization of ( $t$-BMA-co-CMA) could be controlled via the RAFT mechanism.

Purified polymers were analyzed by ${ }^{1} \mathrm{H}$ NMR using $\mathrm{CDCl}_{3}$ as the solvent (Figure S7A, Supporting Information). Signals at 5.3 and $4.5 \mathrm{ppm}$, indicative of one olefinic proton in cholesterol moiety and methine, -COO- $\mathrm{CH}-$, the main link between cholesterol moiety and ester group, were observed in equal intensities, suggesting that the cholesterol units stay intact during polymerization process.

To obtain polymers with varying cholesterol contents, polymerizations were performed with increasing CMA content 
in the feed (Table 2). The composition of the copolymers could be calculated from the integrations of relevant proton

Table 2. Copolymers of t-BMA and CMA Prepared at Varying Compositions

$\begin{array}{cccccc}\begin{array}{c}\text { CMA in the } \\ \text { feed (mol } \\ \% \text { of total } \\ \text { monomer) }\end{array} & \begin{array}{c}\text { CMA in the } \\ \text { copolymer } \\ \text { (mol \% of } \\ \text { resultant } \\ \text { copolymer) }\end{array} & \begin{array}{c}\text { CMA in the } \\ \text { copolymer } \\ \text { (wt \% of } \\ \text { resultant } \\ \text { copolymer) }\end{array} & \begin{array}{c}\text { conversion } \\ (\%)\end{array} & \begin{array}{c}M_{\mathrm{n}}{ }^{c} \\ (\mathrm{~g} / \mathrm{mol})\end{array} & \text { PDI }^{d} \\ 2 & 2 & 6 & 73 & 16500 & 1.19 \\ 4 & 4 & 12 & 76 & 15800 & 1.10 \\ 8 & 8 & 23 & 69 & 18000 & 1.11 \\ 10 & 10 & 28 & 64 & 17900 & 1.14 \\ 12 & 12 & 32 & 60 & 18300 & 1.08 \\ 13 & 13 & 34 & 62 & 18600 & 1.27 \\ 15 & 16 & 40 & 67 & 21700 & 1.23\end{array}$

${ }^{a}[$ Total monomer $] /[\mathrm{RAFT}] /[\mathrm{AIBN}]$ molar ratio in the feed $=204.0 /$ 1.0/0.2. Total monomer concentration in the feed, $4.08 \mathrm{M}$; polymerization temperature, $68{ }^{\circ} \mathrm{C}$; solvent, toluene. ${ }^{b}$ Monomer conversion determined by ${ }^{1} \mathrm{H}$ NMR. ${ }^{c}$ The number of average molecular weight determined by THF GPC analysis using PS standards. ${ }^{d}$ Polydispersity index.

signals in the ${ }^{1} \mathrm{H}$ NMR spectra. The total integration between 2.4 and $0.6 \mathrm{ppm}$ illustrates overlapping t-BMA, 14H, and cholesterol moiety, $48 \mathrm{H}$ peaks. The mole ratio was calculated by the following equation: CMA mol $\%=\left[\int a /\left(\left(\left(\int v-(48 \times\right.\right.\right.\right.$ $\left.\left.\left.\left.\left.\int a\right)\right) / 14\right)+\int a\right)\right] \times 100 ; \mathrm{t}-\mathrm{BMA} \mathrm{mol} \%=\left[\left(\left(\int v-(48 \times\right.\right.\right.$ $\left.\left.\left.\left.\int a\right)\right) / 14\right) /\left(\left(\left(\int v-\left(48 \times \int a\right)\right) / 14\right)+\int a\right)\right] \times 100$ (Figure S7A, Supporting Information). According to the NMR analysis (Table 2), the copolymer composition (between 60 and $76 \%$ monomer conversions) was the same as the comonomer feed, suggesting a statistical placement of the two monomers along the copolymer chain and almost equal reactivity of the monomers toward both propagating species. In this study, statistical copolymers instead of block copolymers were intended to be synthesized to minimize phase segregation of cholesterol units in aqueous solution (avoid from micellization) and maximize their interaction with lipid membranes.
Conversion of tert-butyl ester to carboxylic acids was achieved by treating $\mathrm{P}(\mathrm{t}-\mathrm{BMA}-\mathrm{co}-\mathrm{CMA})$ with TFA at room temperature for $32 \mathrm{~h}$ (Scheme 1, step 2). TFA treatment was chosen due to its selectivity in cleaving tert-butyl ester groups without affecting other types of esters. ${ }^{63}$ Initially the reaction was conducted on $\mathrm{P}(\mathrm{t}-\mathrm{BMA})$ and the specific deprotection of tert-butyl groups was monitored by ${ }^{1} \mathrm{H} \mathrm{NMR}$ at different time intervals (Scheme S3 and Figures S4 and S5, Supporting Information). Indication of hydrolysis being complete was determined by the disappearance of the tert-butyl protons peak at $1.41 \mathrm{ppm}$ along with the formation of an acidic proton at $12.04 \mathrm{ppm}^{64}$ The signals intensity decreased proportional to time; after $16 \mathrm{~h}$, the tert-butyl group had nearly disappeared, although the reaction was continued to remove side products such as $\mathrm{CF}_{3} \mathrm{C}\left(\mathrm{CH}_{3}\right)_{3}(1.01 \mathrm{ppm})$ and $\mathrm{OHC}\left(\mathrm{CH}_{3}\right)_{3}(1.19 \mathrm{ppm}$, $4.64 \mathrm{ppm})$. Extended reaction time resulted in a clearer hydrolysis with minimum side products (Figure S4, Supporting Information). ${ }^{65}$ In a control experiment, the effects of acid hydrolysis on PCMA were investigated. PCMA was treated with TFA for $32 \mathrm{~h}$ (Figure S6, Supporting Information). Results indicated that acid hydrolysis conditions applied for the cleavage of tert-butyl ester had no effect on $\mathrm{P}(\mathrm{CMA})$ ensuring this treatment to be applicable to $\mathrm{P}(\mathrm{t}-\mathrm{BMA}-\mathrm{co}-\mathrm{CMA})$.

Subsequently, acid hydrolysis was performed on $\mathrm{P}(\mathrm{t}-\mathrm{BMA}-\mathrm{co}$ CMA) and monitored by ${ }^{1} \mathrm{H}$ NMR in DMSO revealing successful deprotection of tert-butyl groups (Figure S7, Supporting Information). The dramatic change in solubility of the polymers (becoming soluble in aqueous solution) upon acid treatment was also an indicator that the ester bonds had been cleaved. Subsequent to acid hydrolysis, copolymers having 2 , 4, and $8 \mathrm{~mol} \%$ CMA became water-soluble. With the increase in cholesterol content (more than $8 \mathrm{~mol} \%$ ), the deprotected copolymers, $\mathrm{P}$ (MAA-co-CMA), seemed to remain water insoluble. The water-soluble copolymers (having 2, 4, and $8 \mathrm{~mol} \% \mathrm{CMA}$ ) were used for further analysis.

The thermal properties of the copolymers were briefly examined via differential scanning calorimetry (DSC). Single glass transition temperatures $\left(T_{\mathrm{g}}\right)$ were observed for homopolymers and copolymers in the range of $82-228{ }^{\circ} \mathrm{C}$ (Figure S8, Supporting Information). Poly(cholesteryl methacrylate)

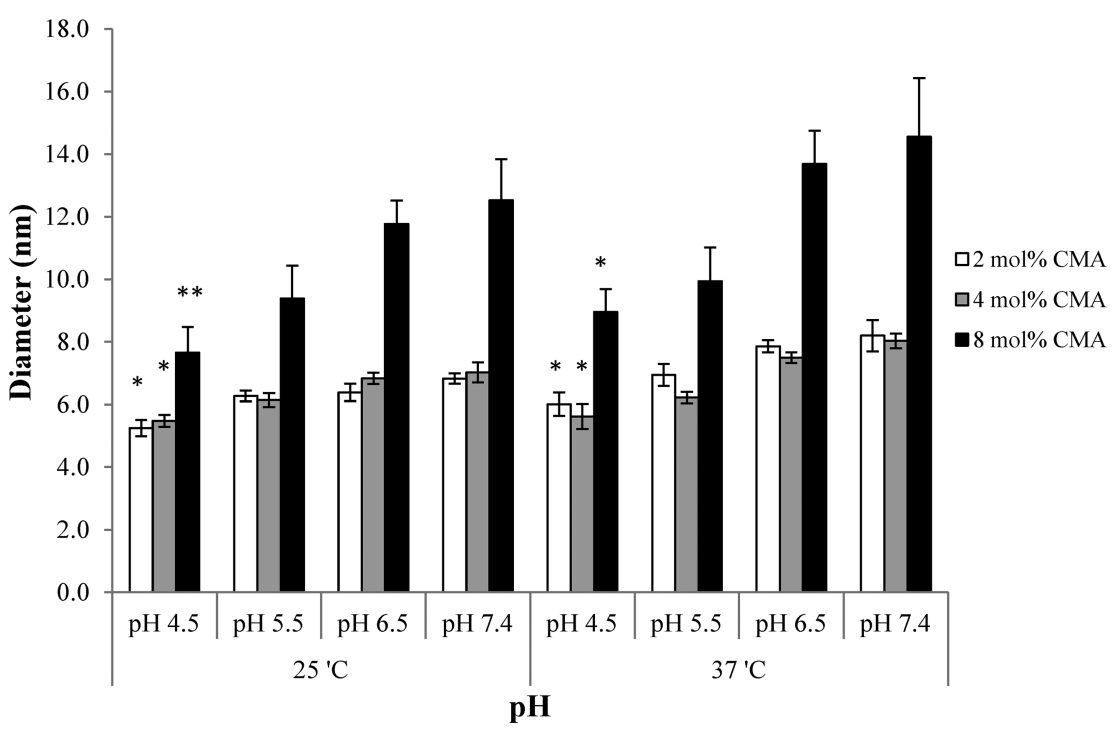

Figure 2. DLS results of the copolymers $(0.125 \mathrm{mM})$ having 2 , 4, and $8 \mathrm{~mol} \% \mathrm{CMA}$ in buffer solutions at varying $\mathrm{pHs}(\mathrm{pH} 4.5,5.5,6.5,7.4)$ at 25 and $37^{\circ} \mathrm{C}$. Anova statistical error values point out the results to be within $* P<0.0005$ and $* * P<0.005$ accuracy. 
(PCMA; $M_{\mathrm{n}, \mathrm{GPC}}, 4000 \mathrm{~g} / \mathrm{mol}$; PDI, 1.13) and poly(methacrylic acid) (P(MAA; $M_{n, G P C}, 36000 \mathrm{~g} / \mathrm{mol}$; PDI, 1.17) displayed $T_{\mathrm{g}}$ values at 82 and $228{ }^{\circ} \mathrm{C}$ respectively, consistent with literature. ${ }^{50,66}$ A representative DSC thermogram of copolymer $\mathrm{P}$ (MAA-co-CMA) (8 mol \% CMA) exhibited a $T_{\mathrm{g}}$ of $168{ }^{\circ} \mathrm{C}$ valued between the two homopolymer transition temperatures. The existence of a single glass-transition temperature indicated the absence of microphase separations, suggesting an overall statistical copolymer structure. $^{67}$

The copolymers (at $0.125 \mathrm{mM}$ concentration in isotonic buffer solutions at varying $\mathrm{pH}$ values) were investigated by dynamic light scattering (DLS) in respect to their composition and environmental $\mathrm{pH}$ (Figure 2). Previously, light scattering analysis conducted on PMAA demonstrated intrachain rearrangements, from a coiled conformation to an expanded open chain state, between $\mathrm{pH} 4$ and $\mathrm{pH} 6$, triggering the chains to swell and increase the polymer size. ${ }^{31,68,69}$ According to the results, the number average hydrodynamic diameter of copolymers having $2 \mathrm{~mol} \% \mathrm{CMA}\left(M_{\mathrm{n}, \mathrm{GPC}}, 16500 \mathrm{~g} / \mathrm{mol}\right.$; PDI, 1.19) and $4 \mathrm{~mol} \% \mathrm{CMA}\left(M_{\mathrm{n}, \mathrm{GPC}}, 15800 \mathrm{~g} / \mathrm{mol}\right.$; PDI, 1.10) ranges from $5 \pm 0.3$ to $7 \pm 0.4 \mathrm{~nm}$, while for the copolymers having $8 \mathrm{~mol} \% \mathrm{CMA}\left(M_{\mathrm{n}, \mathrm{GPC}}, 18000 \mathrm{~g} / \mathrm{mol}\right.$; PDI, 1.11) the diameter shifts to the range between $8 \pm 1.1$ and $13 \pm$ $1.9 \mathrm{~nm}$ at all $\mathrm{pH}$ and temperature values investigated. Size distribution plots (Figure S9, Supporting Information) along with PDI data (Table S1, Supporting Information) obtained from DLS verify the uniform size of copolymers.

The larger hydrodynamic diameter of the copolymer with the highest CMA content suggests the existence of supramolecular organization of the copolymer chains in solution most likely due to the hydrophobic interactions (through the CMA units). It is possible that cholesterol units in the copolymer with $8 \mathrm{~mol}$ \% CMA undergo smectic arrangement leading to the formation of bilayered or partially interdigitated packing of two copolymer chains, ${ }^{35}$ while the copolymers with less CMA content present as unimers due to their higher hydrophilicity, as indicated by their relatively smaller hydrodynamic sizes in comparison to 8 mol \% CMA.

The hydrodynamic diameter of all copolymers increased with the increase in $\mathrm{pH}$. Results are consistent with literature indicating amphiphilic copolymers with carboxylic acid groups have the propensity to exist in expanded random coil conformations at $\mathrm{pHs}$ above their $\mathrm{pK}_{\mathrm{a}}$ in other words at physiologic $\mathrm{pH}(\mathrm{pH} 7.4)$, the copolymers are in their most extended form due to the charge repulsion between their anionic carboxyl groups. ${ }^{70,71}$ Upon $\mathrm{pH}$ change, in acidic medium below their $\mathrm{p} K_{\mathrm{a}}$, polymers tend to protonate forming more globular, collapsed structures, compared to their original conformation at neutral $\mathrm{pH}^{70,72-74}$ This transition can be observed by the decrease in the hydrodynamic radius of the polymer chains, as seen in Figure 2. ${ }^{75}$ The temperature can also affect the hydrodynamic diameter of the copolymers. The temperature change from room temperature to $37^{\circ} \mathrm{C}$ (body temperature) at constant $\mathrm{pH}$ influences the polymer chains to expand, increasing their diameter.

Turbidity Assay. The $\mathrm{pH}$-responsive phase behavior of $\mathrm{P}$ (MAA-co-CMA), comprised with varying CMA units, was determined using UV-vis spectroscopy. The change in absorbance values at $400 \mathrm{~nm}$ for the copolymers in different $\mathrm{pH}$ solutions at $0.125 \mathrm{mM}$ concentration is shown in Figure 3. PMAA, bearing carboxylic acid groups, when ionized at $\mathrm{pH} 6$ (above $\mathrm{p} K_{\mathrm{a}}$ ) exists in an expanded form that is dominated by Coulomb repulsions between the carboxylate anions. Fur-

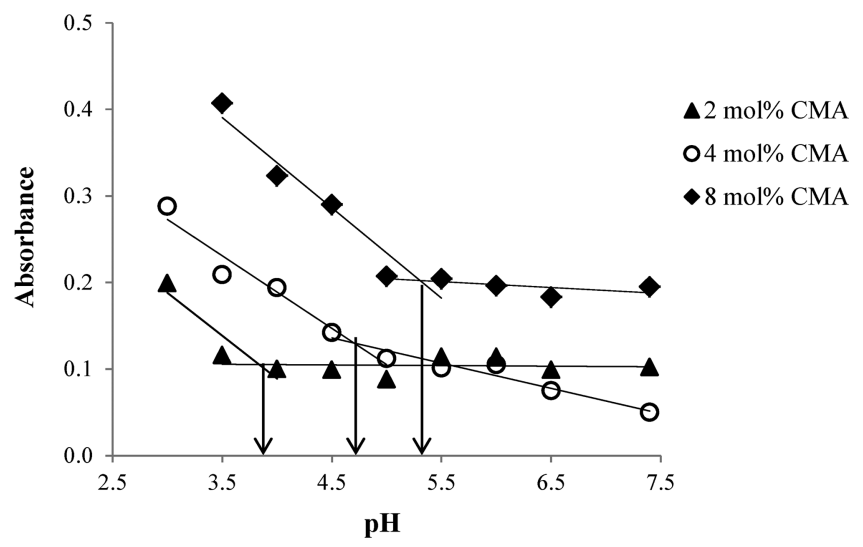

Figure 3. Absorbance values at $400 \mathrm{~nm}$ of copolymers containing 2 mol \% CMA (triangles), 4 mol \% CMA (circles), and $8 \mathrm{~mol} \% \mathrm{CMA}$ (diamonds) in differing $\mathrm{pH}$ solutions at $0.125 \mathrm{mM}$ concentrations.

thermore, below the $\mathrm{p} K_{\mathrm{a}}$ value $(\sim \mathrm{pH} 4)$ the carboxylic acid groups gradually neutralize, which shift PMAA into a more globular, compact conformation. ${ }^{14,73,76,77}$ From previous studies it is clear that the MAA content has a great effect on the amphiphilic balance of the copolymers. As the $\mathrm{pH}$ of the solution is increased, the $\mathrm{COOH} / \mathrm{COO}^{-}$ratio in the copolymer decreases, which makes the copolymer chains more hydrophilic. ${ }^{78}$ In other words, at higher $\mathrm{pH}$, the copolymer chains are in their most soluble state, causing the solution to appear less turbid. With increasing hydrophobicity (higher CMA content), the $\mathrm{pH}$-responsive phase transition values progressively rose from $\mathrm{pH} 3.9$ in the case of $2 \mathrm{~mol} \% \mathrm{CMA}$ and $\mathrm{pH} 4.7$ in the case of $4 \mathrm{~mol} \% \mathrm{CMA}$ to $\mathrm{pH} 5.4$ in the case of $8 \mathrm{~mol} \%$ CMA. This result suggests that decrease in PMAA content of polymers increases the $\mathrm{pH}$ at which they change their conformation from a hydrophilic state to a hydrophobic state. ${ }^{20}$

Atomic Force Microscopy. The larger hydrodynamic diameter and the higher turbidity of the copolymer chains with the highest CMA content ( $8 \mathrm{~mol} \%)$ suggested the selforganization of this copolymer in aqueous solutions, as explained above. To investigate this hypothesis, the copolymers with $2 \mathrm{~mol} \%$ and $8 \mathrm{~mol} \% \mathrm{CMA}$ (at $0.125 \mathrm{mM}$ concentration in buffer solution at $\mathrm{pH}$ 5.0) were investigated by atomic force microscopy (AFM) (Figure 4). As expected, the copolymer with $8 \mathrm{~mol} \% \mathrm{CMA}$ content appeared to form spherical supramolecular structures in aqueous solution at $\mathrm{pH}$ 5.0. This occurs most likely due to the relatively more hydrophobic character of this copolymer which tends to minimize the exposure of the higher number of cholesterol units to solution.
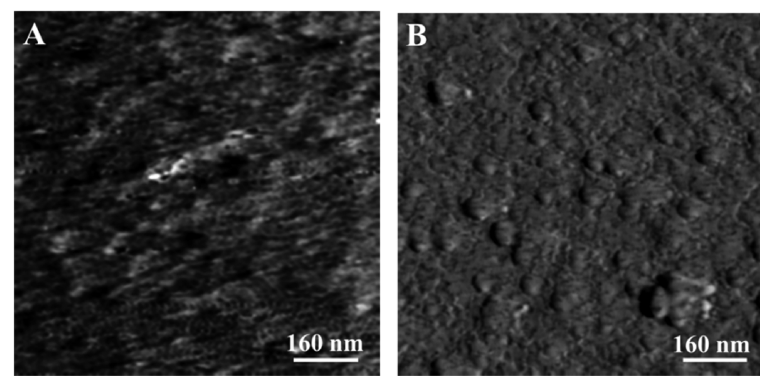

Figure 4. Atomic force microscopy images of the copolymers with (A) $2 \mathrm{~mol} \% \mathrm{CMA}$ and (B) $8 \mathrm{~mol} \%$ CMA. The sample solutions $(0.125$ $\mathrm{mM}$ ) in buffer at $\mathrm{pH} 5.0$ were dropped on silicone substrate and dried at room conditions. 


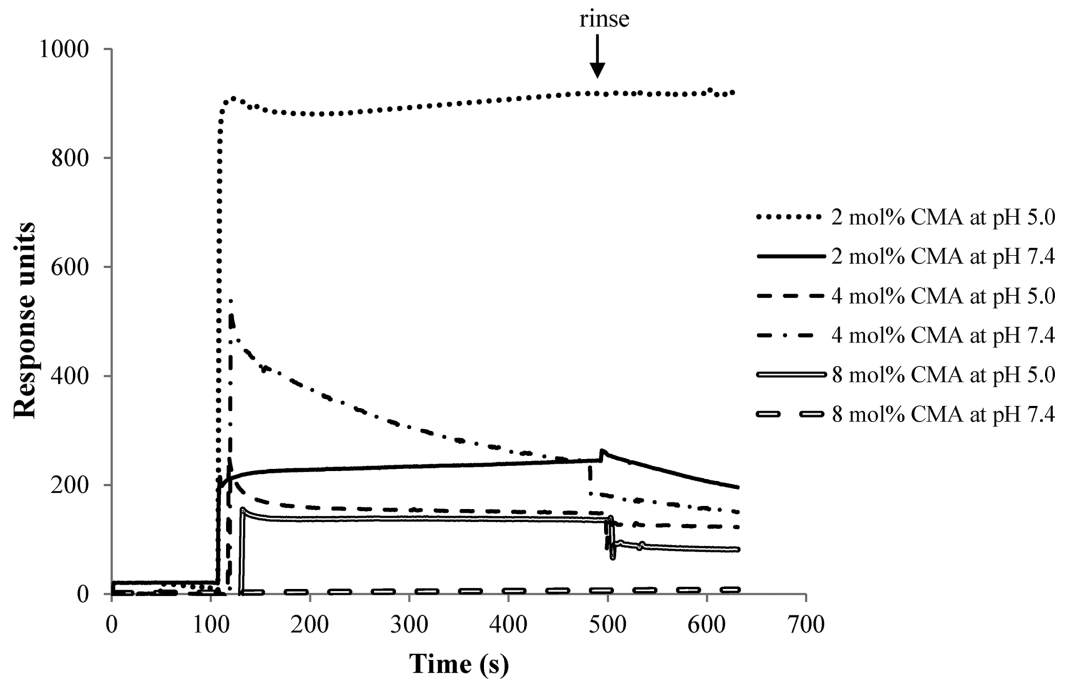

Figure 5. Surface plasmon resonance (SPR) real-time monitoring of binding of the copolymers with 2, 4, or 8 mol \% CMA onto cell plasma membrane-mimicking lipid bilayer (cholesterol/phosphatidylcholine molar ratio of 0.42 ). Polymers $(0.5 \mathrm{mM})$ in buffer solutions at $\mathrm{pH} 5.0$ or 7.4 were injected over the lipid bilayer surface at a flow rate of $20 \mu \mathrm{L} / \mathrm{min}$ for $6.5 \mathrm{~min}$. After reaching saturation, surfaces were rinsed (shown by arrow) with related buffer solutions for the same period of time.

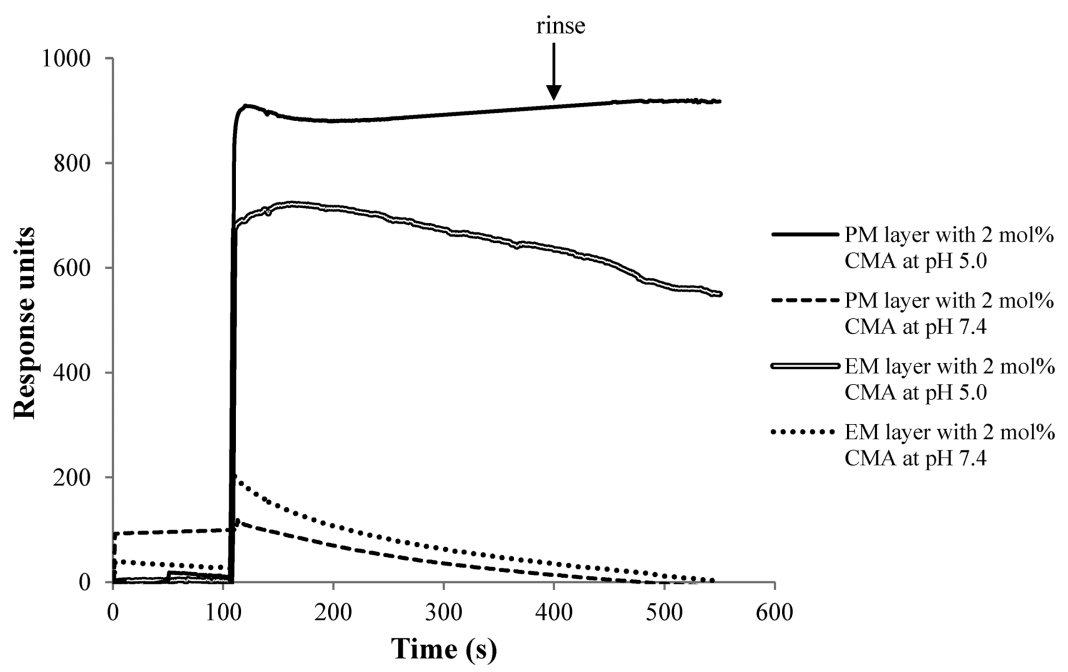

Figure 6. SPR real-time monitoring the binding of the $2 \mathrm{~mol} \%$ CMA copolymer onto lipid bilayer mimicking the plasma (PM) or endosome membrane (EM) in acidic or neutral conditions. PM consisted of cholesterol/phosphatidylcholine constituents at a cholesterol/phosphatidylcholine molar ratio of 0.42 , and EM consisted of cholesterol and phosphatidylcholine at a mole ratio of 0.80 . The related polymer solution ( $0.5 \mathrm{mM})$ was injected over the lipid bilayer surface at a flow rate of $20 \mu \mathrm{L} / \mathrm{min}$ for $6.5 \mathrm{~min}$; upon reaching saturation, it was then rinsed with related buffer solution (indicated by the arrow).

In contrast, the copolymer with 2 mol \% CMA appeared to exist in extended chain conformation because of its higher hydrophilicity compared to the copolymer having $8 \mathrm{~mol} \%$ CMA. This result was in good accord with the results obtained from DLS and turbidity experiments.

Surface Plasmon Resonance. The interactions between polymer molecules and lipid bilayer immobilized surfaces were investigated by SPR. Lipid bilayer comprised of varying cholesterol/phosphatidylcholine constituents were generated as cellular membrane models for the plasma and endosome membranes. ${ }^{54}$ Polymers at $0.5 \mathrm{mM}$ concentration, composed of varying cholesterol units (2, 4, and $8 \mathrm{~mol} \% \mathrm{CMA})$, were interacted first with the plasma membrane-mimicking surfaces in slightly acidic and neutral $\mathrm{pH}$. Surfaces were treated with polymer solutions of $0.5 \mathrm{mM}$ concentration to ensure interaction of the polymer with lipid layer and obtain complete surface coverage. ${ }^{79}$ Figure 5 displays the interaction of the copolymer containing 2 mol \% CMA with lipid bilayer surface at both $\mathrm{pHs}$ to be significantly higher than the interactions of 4 and $8 \mathrm{~mol} \% \mathrm{CMA}$ containing copolymers. As supported by AFM analysis, the higher hydrophobicity of the copolymers with 4 and $8 \mathrm{~mol} \% \mathrm{CMA}$ compared to $2 \mathrm{~mol} \% \mathrm{CMA}$ copolymer might be causing the self-organization of the copolymer chains in aqueous solution to minimize the exposure of hydrophobic cholesterol units to water, which in total reduces the interactions of the cholesterol units along the chains with the lipid layer and, thus, demonstrating lower binding profile. Furthermore, in acidic medium, the copolymer having 2 mol \% CMA exhibits almost five times greater binding when compared with the binding signal intensity of the same copolymer at neutral $\mathrm{pH}$. The increase in surface binding at lower $\mathrm{pH}$ can be explained by the relatively higher hydro- 
phobicity (exposed cholesterol moieties) along with the lower ionic charge (protonated MAA units) of the copolymer, possibly increasing the interaction of the copolymer chains with phosphatidylcholine/cholesterol lipid bilayer. ${ }^{74,80}$

Upon determining the copolymer composition displaying the highest binding to the plasma membrane-mimicking surface, the polymer-lipid interaction was further investigated in relation to lipid bilayer composition (Figure 6). The interaction of the 2 mol \% CMA copolymer with plasma or endosome membrane-mimicking lipid bilayer arrangements having different cholesterol contents (molar ratio of 0.42 and 0.80 , respectively) were compared in a $\mathrm{pH}$-dependent manner using SPR. The binding of the copolymer with both lipid bilayers at acidic $\mathrm{pH}$ was higher when compared with the binding at neutral $\mathrm{pH}$, as expected. Interestingly, the binding at acidic condition with the plasma membrane-mimicking bilayer was higher than the binding with endosome membranemimicking bilayer which had almost 2-fold higher cholesterol content. This was attributed to the possible interactions formed among protonated MAA units of the copolymer and phophatidylcholine components in the lipid bilayer surfaces. Intermolecular hydrogen bonding created at acidic $\mathrm{pH}$ between phosphatidylcholine units (higher content in plasma membrane-mimicking bilayer) and copolymer chains is likely to dominate intra- and intermolecular hydrogen bonds between MAA units along copolymer chains, consequently leading to greater interactions with the lipid bilayer. ${ }^{81,82}$ It is also possible that the higher rigidity of the endosome membrane-mimicking bilayer because of the higher cholesterol content decreases the interaction of the bilayer with the polymer chains. Consistent with these results, at $\mathrm{pH} 7.4$ there was almost no binding with both membrane models, possibly because of the electrostatic repulsion between negatively charged copolymers and anionic lipid bilayer.

Liposome Lysis Assay. The extent of $\mathrm{pH}$-dependent hydrophobic association of the copolymers has been identified as an important factor in determining the degree of membrane destabilization activity which is required for intracellular drug delivery vehicles. ${ }^{83}$ Amphiphilic copolymers containing 2, 4, and $8 \mathrm{~mol} \% \mathrm{CMA}$, were analyzed for their $\mathrm{pH}$-dependent membrane-lytic properties using a liposome leakage assay, as described in the literature. ${ }^{84}$ The assay was first performed by treating the SRB-loaded liposomes with copolymer solutions at $0.125 \mathrm{mM}$ concentrations at $\mathrm{pH} 5.0$ and 7.4. Complete release of SRB from liposomes was observed with no $\mathrm{pH}$-dependent profile (data not shown). This suggests that the copolymers at $0.125 \mathrm{mM}$ cause nonspecific ( $\mathrm{pH}$-independent) destabilization of liposomes causing the leakage of SRB at both $\mathrm{pH}$ values tested ( $\mathrm{pH} 5.0$ and 7.4). Here it should be noted that the copolymers at a higher concentration $(0.5 \mathrm{mM})$ show $\mathrm{pH}$ dependent interaction with the lipid layer anchored onto a surface (as SPR results indicated). The discrepancy between the results obtained from SPR and liposome leakage assay might be due to the fact that the lipid assembly on the surface is well-packed and, thus, less flexible than the lipid layer of liposomes, which minimizes the interactions with the copolymer chains at ionized (hydrophilic) state (at $\mathrm{pH}$ 7.4) even at high concentrations such as $0.5 \mathrm{mM}$.

The liposome leakage assay was repeated using copolymer solutions at much lower concentrations $(1.5$ and $3.0 \mu \mathrm{M})$ to avoid from nonspecific ( $\mathrm{pH}$-independent) destabilization of liposomes. Based on the release profiles of SRB from liposomes after incubation with the copolymers, the $\mathrm{pH}$-dependent membrane-lytic effect of the copolymer containing $2 \mathrm{~mol} \%$ CMA, was found to be the strongest (Figure 7). This result, in
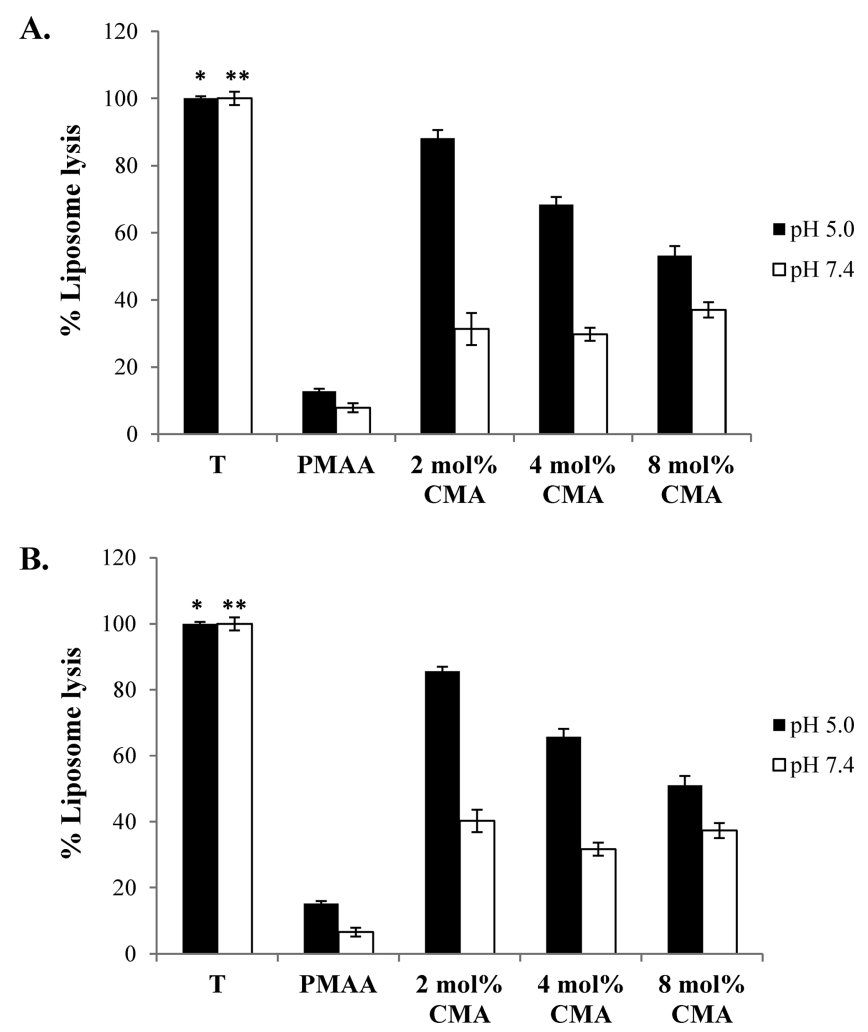

Figure 7. Results of liposome lysis assay. The lysis obtained with the copolymers containing 2, 4, and $8 \mathrm{~mol} \% \mathrm{CMA}$ are shown in the graph, PMAA represents lysis gained by poly(methacrylic acid) only (with no cholesterol units), and $10 \%$ Triton X-100 (T) signifies maximum lysis. Polymer concentrations are (A) 1.5 or (B) $3.0 \mu \mathrm{M}$. The results are the average of two different sets of experiments performed in triplicate. Error bars represent standard deviation. Anova statistical analysis results reveal the values to be within $* P<0.05$ and $* * P<0.006$ accuracy.

accord with the SPR data reveals that the copolymer having 2 mol \% CMA exhibits the greatest polymer-lipid interactions and displays the highest membrane destabilization activity at $\mathrm{pH}$ 5.0. The lower membrane-lytic activity of the copolymers with higher CMA content can be attributed to the selforganization of these copolymers in solution, minimizing the hydrophobic interactions between copolymer CMA units and liposomes. Amphiphilic polymers have been shown to interact with lipid vesicles by inserting their hydrophobic segments into the lipid layer as a result of the hydrophobic interactions. ${ }^{85}$

The liposome lysis by the copolymers was observed to be pH-dependent. ${ }^{86,87}$ The membrane-lytic activity at $\mathrm{pH} 5.0$ was 3 -fold (in the case of 2 mol \% CMA), 2-fold (4 mol \% CMA), and 1.4-fold higher ( $8 \mathrm{~mol} \% \mathrm{CMA}$ ) than the lysis at $\mathrm{pH} 7.4$. The copolymers displayed an average of 34\% SRB leakage at neutral $\mathrm{pH}$. Similar residual lytic activities at neutral $\mathrm{pH}$ have also been reported previously for various $\mathrm{pH}$-dependent membrane disruptive polymers. ${ }^{21,70,88}$ As the $\mathrm{pH}$ of the solution is increased, the copolymer chains become negatively charged and more hydrophilic because of the ionization of the carboxylic acid groups of MAA units. ${ }^{78}$ This decreases the interactions between phophatidylcholine liposomes and the copolymer chains. Hydrogen bonds that may form at acidic 
pHs between the carboxylate groups of the copolymer chains and the phosphate groups of phophatidylcholine molecules may also help the destabilization of the membrane leading to SRB leakage from the liposome. The deficiency of lysis activity in our control group, PMAA acidic polymer, shows that the membrane interaction is mediated by the copolymers hydrophobic cholesterol units. In summary, both hydrophobic interactions and $\mathrm{H}$-bonding play a role in lipid membrane destabilization; however, the significant ratio of these two interactions present in a polymer dictates the aptitude of membrane disruption. Changing the polymer concentration from 1.5 to $3.0 \mu \mathrm{M}$ did not have an effect on the extent of lysis (Figure 7). Overall results suggest that the copolymers of MAA and CMA are membrane-lytic, and their lysis ability differs according to their CMA content and $\mathrm{pH}$ of the environment. Moreover, the $\mathrm{pH}$-dependent lysis ability of the copolymer with 2 mol \% CMA potentially demonstrates the desired profile of endosomolytic polymers used for intracellular drug delivery. ${ }^{16,20,26,71}$

Determination of Cell Viability via CellTiter-Blue Assay. Finally, P(MAA-co-CMA), with varying CMA contents, were characterized with regard to their effects on viability of human neuroblastoma SH-EP cells by CellTiter-Blue assay. This assay is based on the ability of viable cells to convert the redox dye resazurin into the fluorescent end product, resorufin. Results of in vitro viability experiments after $72 \mathrm{~h}$ of incubation of the cells with different concentrations of polymers, ranging from 0.06 to $30 \mu \mathrm{M}$ (per $3 \times 10^{3}$ cells), are shown in Figure 8 . Cell viability (\%) is expressed as a function against the untreated cells (control for $100 \%$ viability) and $10 \%$ Triton X100 treatment (control for $0 \%$ viability).

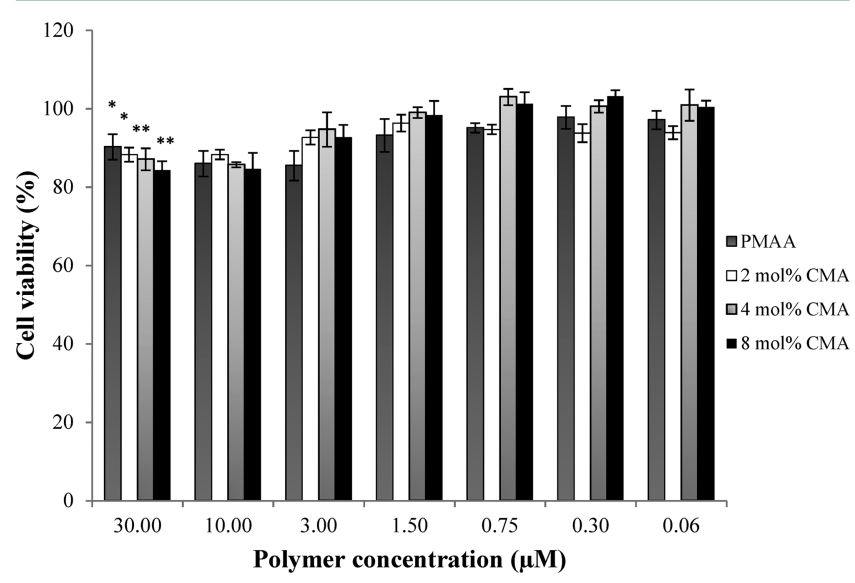

Figure 8. Viability of human neuroblastoma SH-EP cells after incubation with $\mathrm{P}$ (MAA-co-CMA) copolymers that consist of 2, 4, and $8 \mathrm{~mol} \%$ CMA along with $\mathrm{P}(\mathrm{MAA})$ for $72 \mathrm{~h}$, measured with CellTiter-Blue assay. The assay was repeated three times in triplicate and the viability results were normalized according to the positive control (untreated cells). Error bars represent standard deviation. Anova statistical error values point out the results to be within ${ }^{*} P<$ 0.06 and $* * P<0.001$ accuracy.

Statistical copolymers composed of 2, 4, and $8 \mathrm{~mol} \% \mathrm{CMA}$ along with $\mathrm{P}(\mathrm{MAA})$ at the concentrations tested displayed similar behavior on the cells. The viability of the cells for $30 \mu \mathrm{M}$ to $0.06 \mu \mathrm{M}$ treatments varied between 86 and $100 \%$, indicating no significant toxicity of the copolymers.

\section{CONCLUSION}

In summary, well-defined statistical copolymers of P(MAA-coCMA), with varying cholesterol content, were synthesized via RAFT polymerization. Controlled composition and narrow molecular weight distributions were obtained for both homopolymers and statistical copolymers. The shift in turbidity of copolymer solutions together with the change in hydrodynamic radii up on $\mathrm{pH}$ adjustments revealed the $\mathrm{pH}$ responsive phase behavior of the copolymers. SPR studies along with the liposome leakage assay indicated that these copolymers, depending on their CMA content and the $\mathrm{pH}$, can interact with the lipid bilayer. In vitro cell viability assays, conducted on human neuroblastoma SH-EP cell line, evidenced that these copolymers display no substantial toxicity at the concentrations tested.

These results support the value of $\mathrm{P}(\mathrm{MAA}-\mathrm{co}-\mathrm{CMA})$ for further investigating their use in the development of intracellular drug delivery vehicles. It would be possible to incorporate cationic substitutes with these new anionic polymers and negatively charged RNA/DNA based therapeutics. Future work will focus on the investigation of the copolymer molecular weight on the membrane-lytic activity and the preparation of $\mathrm{P}(\mathrm{MAA}-\mathrm{co}-\mathrm{CMA})$ containing polyplex formulations with difficult-to-deliver biological macromolecules, such as short interfering RNA (siRNA) and DNA, and the testing of their efficacy in cytoplasmic delivery.

\section{ASSOCIATED CONTENT}

\section{Supporting Information}

Experimental methods for synthesis of cholesteryl methacrylate (CMA) monomer, homopolymerizations of CMA and t-BMA, and acid hydrolysis, differential scanning calorimetry traces, and representative size distribution plots of copolymers, Schemes S1-S3, Figures S1-S9, and Table S1. This material is available free of charge via the Internet at http://pubs.acs.org.

\section{AUTHOR INFORMATION}

\section{Corresponding Author}

*Tel.: +90-232-750 6660. E-mail: volgabulmus@iyte.edu.tr.

\section{Notes}

The authors declare no competing financial interest.

\section{ACKNOWLEDGMENTS}

The authors acknowledge The University of New South Wales Gold Star Award and Dr. Ling-Jiun Wong for her help on preliminary literature search. V.B. also acknowledges The Scientific and Technological Research Council of Turkey (TUBITAK) for research Grant No. 111T960.

\section{REFERENCES}

(1) Jones, A. T.; Gumbleton, M.; Duncan, R. Adv. Drug Delivery Rev. 2003, 55 (11), 1353-1357.

(2) Zhao, F.; Zhao, Y.; Liu, Y.; Chang, X.; Chen, C.; Zhao, Y. Small 2011, 7 (10), 1322-1337.

(3) Pack, D. W.; Hoffman, A. S.; Pun, S.; Stayton, P. S. Nat. Rev. Drug Discovery 2005, 4 (7), 581-593.

(4) Troiber, C.; Wagner, E. Bioconjugate Chem. 2011, 22 (9), 17371752.

(5) Varkouhi, A. K.; Scholte, M.; Storm, G.; Haisma, H. J. J. Controlled Release 2011, 151 (3), 220-228.

(6) Mukherjee, S.; Ghosh, R. N.; Maxfield, F. R. Physiol. Rev. 1997, 77 (3), 759-803. 
(7) Huang, Z. H.; Li, W. J.; MacKay, J. A.; Szoka, F. C. Mol. Ther. 2005, 11 (3), 409-417.

(8) Wolfrum, C.; Shi, S.; Jayaprakash, K. N.; Jayaraman, M.; Wang, G.; Pandey, R. K.; Rajeev, K. G.; Nakayama, T.; Charrise, K.; Ndungo, E. M.; Zimmermann, T.; Koteliansky, V.; Manoharan, M.; Stoffel, M. Nat. Biotechnol. 2007, 25 (10), 1149-1157.

(9) Soutschek, J.; Akinc, A.; Bramlage, B.; Charisse, K.; Constien, R.; Donoghue, M.; Elbashir, S.; Geick, A.; Hadwiger, P.; Harborth, J.; John, M.; Kesavan, V.; Lavine, G.; Pandey, R. K.; Racie, T.; Rajeev, K. G.; Rohl, I.; Toudjarska, I.; Wang, G.; Wuschko, S.; Bumcrot, D.; Koteliansky, V.; Limmer, S.; Manoharan, M.; Vornlocher, H.-P. Nature 2004, 432 (7014), 173-178.

(10) Meyer, M.; Philipp, A.; Oskuee, R.; Schmidt, C.; Wagner, E. J. Am. Chem. Soc. 2008, 130 (11), 3272-3273.

(11) Torchilin, V. P. Biopolymers 2008, 90 (5), 604-610.

(12) Stewart, K. M.; Horton, K. L.; Kelley, S. O. Org. Biomol. Chem. 2008, 6 (13), 2242-2255.

(13) Li, W. J.; Nicol, F.; Szoka, F. C. Adv. Drug Delivery Rev. 2004, 56 (7), 967-985.

(14) Bulmus, V.; Woodward, M.; Lin, L.; Murthy, N.; Stayton, P.; Hoffman, A. J. Controlled Release 2003, 93 (2), 105-120.

(15) Hoffman, A. S.; Stayton, P. S.; Ei-Sayed, M. E. H.; Murthy, N.; Bulmus, V.; Lackey, C.; Cheung, C. J. Biomed. Nanotechnol. 2007, 3, 213-217.

(16) Murthy, N.; Robichaud, J. R.; Tirrell, D. A.; Stayton, P. S.; Hoffman, A. S. J. Controlled Release 1999, 61 (1-2), 137-143.

(17) Grube, S.; Wolfrurn, U.; Langguth, P. Biomacromolecules 2008, 9 (5), 1398-1405.

(18) Yessine, M. A.; Dufresne, M. H.; Meier, C.; Petereit, H. U.; Leroux, J. C. Bioconjugate Chem. 2007, 18 (3), 1010-1014.

(19) Funhoff, A. M.; Van Nostrum, C. F.; Lok, M. C.; Kruijtzer, J. A. W.; Crommelin, D. J. A.; Hennink, W. E. J. Controlled Release 2005, $101(1-3), 233-246$.

(20) Convertine, A. J.; Benoit, D. S. W.; Duvall, C. L.; Hoffman, A. S.; Stayton, P. S. J. Controlled Release 2009, 133 (3), 221-229.

(21) Henry, S. M.; El-Sayed, M. E. H.; Pirie, C. M.; Hoffman, A. S.; Stayton, P. S. Biomacromolecules 2006, 7 (8), 2407-2414.

(22) Foster, S.; Duvall, C. L.; Crownover, E. F.; Hoffman, A. S.; Stayton, P. S. Bioconjugate Chem. 2010, 21 (12), 2205-2212.

(23) Convertine, A. J.; Diab, C.; Prieve, M.; Paschal, A.; Hoffman, A. S.; Johnson, P. H.; Stayton, P. S. Biomacromolecules 2010, 11 (11), 2904-2911.

(24) Duvall, C. L.; Convertine, A. J.; Benoit, D. S. W.; Hoffman, A. S.; Stayton, P. S. Mol. Pharm. 2010, 7 (2), 468-476.

(25) Benoit, D. S. W.; Srinivasan, S.; Shubin, A. D.; Stayton, P. S. Biomacromolecules 2011, 12 (7), 2708-2714.

(26) Benoit, D. S. W.; Henry, S. M.; Shubin, A. D.; Hoffman, A. S.; Stayton, P. S. Mol. Pharm. 2010, 7 (2), 442-455.

(27) Murthy, N.; Campbell, J.; Fausto, N.; Hoffman, A. S.; Stayton, P. S. J. Controlled Release 2003, 89 (3), 365-374.

(28) Cheung, C. Y.; Murthy, N.; Stayton, P. S.; Hoffman, A. S. Bioconjugate Chem. 2001, 12 (6), 906-910.

(29) Lackey, C. A.; Press, O. W.; Hoffman, A. S.; Stayton, P. S. Bioconjugate Chem. 2002, 13 (5), 996-1001.

(30) Kyriakides, T. R.; Cheung, C. Y.; Murthy, N.; Bornstein, P.; Stayton, P. S.; Hoffman, A. S. J. Controlled Release 2002, 78 (1-3), 295-303.

(31) Sant, V. P.; Smith, D.; Leroux, J.-C. J. Controlled Release 2004, 97 (2), 301-312.

(32) Yang, Y. Q.; Zheng, L. S.; Guo, X. D.; Qian, Y.; Zhang, L. J. Biomacromolecules 2010, 12 (1), 116-122.

(33) Schüwer, N.; Klok, H.-A. Langmuir 2011, 27 (8), 4789-4796.

(34) Alarcon, C. d. 1. H.; Pennadam, S.; Alexander, C. Chem. Soc. Rev. 2005, 34 (3), 276-285.

(35) Zhou, Y.; Briand, V.; Sharma, N.; Ahn, S.-k.; Kasi, R. Materials 2009, 2 (2), 636-660.

(36) Wen, J.; Mao, H.-Q.; Li, W.; Lin, K. Y.; Leong, K. W. J. Pharm. Sci. 2004, 93 (8), 2142-2157.
(37) Gu, Z. X.; Yuan, Y.; He, J. L.; Zhang, M. Z.; Ni, P. H. Langmuir 2009, 25 (9), 5199-5208.

(38) Zhou, Y.; Sharma, N.; Deshmukh, P.; Lakhman, R. K.; Jain, M.; Kasi, R. M. J. Am. Chem. Soc. 2011, 134 (3), 1630-1641.

(39) Bajaj, A.; Kondaiah, P.; Bhattacharya, S. Bioconjugate Chem. 2008, 19, 1640-1651.

(40) Kim, W. J.; Chang, C. W.; Lee, M.; Kim, S. W. J. Controlled Release 2007, 118 (3), 357-363.

(41) Incani, V.; Lavasanifar, A.; Uludag, H. Soft Matter 2010, 6 (10), 2124-2138.

(42) Jones, S. P.; Gabrielson, N. P.; Pack, D. W.; Smith, D. K. Chem. Commun. (Cambridge, U.K.) 2008, 39, 4700-4702.

(43) Ikonen, E. Nat. Rev. Mol. Cell Biol. 2008, 9 (2), 125-138.

(44) Boyer, C.; Bulmus, V.; Davis, T. P.; Ladmiral, V.; Liu, J. Q.; Perrier, S. Chem. Rev. 2009, 109 (11), 5402-5436.

(45) Smith, D.; Holley, A. C.; McCormick, C. L. Polym. Chem. 2011, 2 (7), 1428-1441.

(46) Xu, X.; Flores, J. D.; McCormick, C. L. Macromolecules 2011, 44 (6), 1327-1334.

(47) Huang, X.; Boyer, C.; Davis, T. P.; Bulmus, V. Polym. Chem. 2011, 2 (7), 1505-1512.

(48) Bulmus, V. Polym. Chem. 2011, 2 (7), 1463-1472.

(49) Sevimli, S.; Sagnella, S.; Kavallaris, M.; Bulmus, V.; Davis, T. P. Polym. Chem. 2012, 3 (8), 2057-2069.

(50) Zhou, Y. X.; Kasi, R. M. J. Polym. Sci., Part A: Polym. Chem. 2008, 46 (20), 6801-6809.

(51) Mitsukami, Y.; Donovan, M. S.; Lowe, A. B.; McCormick, C. L. Macromolecules 2001, 34 (7), 2248-2256.

(52) Thang, S. H.; Chong, Y. K.; Mayadunne, R. T. A.; Moad, G.; Rizzardo, E. Tetrahedron Lett. 1999, 40 (12), 2435-2438.

(53) Chen, G. H.; Hoffman, A. S. Macromol. Chem. Phys. 1995, 196 (4), 1251-1259.

(54) Evans, W. H.; Hardison, W. G. M. Biochem. J. 1985, 232 (1), 33-36.

(55) Morrissey, J. H. Morrissey Laboratory Protocol for Preparing Phospholipid Vesicles (SUV) by Sonication; Department of Biochemistry, University of Illinois: Urbana-Champaign, Urbana, IL 61801, 2001; http://tf7.org/suv.pdf.

(56) Wong, L. J.; Boyer, C.; Jia, Z. F.; Zareie, H. M.; Davis, T. P.; Bulmus, V. Biomacromolecules 2008, 9 (7), 1934-1944.

(57) Kilian, L.; Wang, Z. H.; Long, T. E. J. Polym. Sci., Part A: Polym. Chem. 2003, 41 (19), 3083-3093.

(58) Deporter, C. D.; Long, T. E.; McGrath, J. E. Polym. Int. 1994, 33 (2), 205-216.

(59) Mengel, C.; Meyer, W. H.; Wegner, G. Macromol. Chem. Phys. 2001, 202 (7), 1138-1149.

(60) Lee, S. C.; Kim, K. J.; Jeong, Y. K.; Chang, J. H.; Choi, J. Macromolecules 2005, 38 (22), 9291-9297.

(61) Nystrom, A. M.; Wooley, K. L. Tetrahedron 2008, 64 (36), $8543-8552$

(62) El-Sayed, M. E. H.; Hoffman, A. S.; Stayton, P. S. Expert Opin. Biol. Ther. 2005, 5 (1), 23-32.

(63) Jiang, X.; Zhao, B. Macromolecules 2008, 41 (23), 9366-9375.

(64) Choi, W. J.; Kim, Y. B.; Kwon, S. K.; Lim, K. T.; Choi, S. K. J. Polym. Sci., Part A: Polym. Chem. 1992, 30 (10), 2143-2148.

(65) Ma, Q. G.; Wooley, K. L. J. Polym. Sci., Part A: Polym. Chem. 2000, 38, 4805-4820.

(66) Lai, J. H. Macromolecules 1984, 17 (5), 1010-1012.

(67) Odian, G. G. Principles of Polymerization, 4th ed.; John Wiley \& Sons, Inc.: New York, 2004; Vol. 1, pp 140-141.

(68) Ruiz-Perez, L.; Pryke, A.; Sommer, M.; Battaglia, G.; Soutar, I.; Swanson, L.; Geoghegan, M. Macromolecules 2008, 41 (6), 22032211.

(69) Heitz, C.; Rawiso, M.; François, J. Polymer 1999, 40 (7), 16371650.

(70) Kusonwiriyawong, C.; van de Wetering, P.; Hubbell, J. A.; Merkle, H. P.; Walter, E. Eur. J. Pharm. Biopharm. 2003, 56 (2), 237246. 
(71) Yessine, M. A.; Leroux, J. C. Adv. Drug Delivery Rev. 2004, 56 (7), 999-1021.

(72) Borden, K. A.; Eum, K. M.; Langley, K. H.; Tirrell, D. A. Macromolecules 1987, 20 (2), 454-456.

(73) Olea, A. F.; Thomas, J. K. Macromolecules 1989, 22 (3), 11651169.

(74) Linhardt, J. G.; Tirrell, D. A. Langmuir 2000, 16 (1), 122-127.

(75) Bulmus, V. Aust. J. Chem. 2005, 58 (6), 411-422.

(76) Yessine, M. A.; Lafleur, M.; Meier, C.; Petereit, H. U.; Leroux, J.C. Biochim. Biophys. Acta, Biomembr. 2003, 1613 (1-2), 28-38.

(77) Joyce, D. E.; Kurucsev, T. Polymer 1981, 22 (3), 415-417.

(78) Bulmus, V.; Ding, Z. L.; Long, C. J.; Stayton, P. S.; Hoffman, A. S. Bioconjugate Chem. 2000, 11 (1), 78-83.

(79) Kim, Y.-R.; Paik, H.-j.; Ober, C. K.; Coates, G. W.; Mark, S. S.; Ryan, T. E.; Batt, C. A. Macromol. Biosci. 2006, 6 (2), 145-152.

(80) Fujiwara, M.; Grubbs, R. H.; Baldeschwieler, J. D. J. Colloid Interface Sci. 1997, 185 (1), 210-216.

(81) Bushmarina, N.; Tourne, S.; Giacometti, G.; Signorino-Gelo, F.; Garcia-Alles, L. F.; Cazenave, J.-P.; Hanau, D.; de la Salle, H. FEBS J. 2011, 278 (12), 2022-2033.

(82) Remmel, N.; Locatelli-Hoops, S.; Breiden, B.; Schwarzmann, G.; Sandhoff, K. FEBS J. 2007, 274 (13), 3405-3420.

(83) Chen, R. J.; Khormaee, S.; Eccleston, M. E.; Slater, N. K. H. Biomacromolecules 2009, 10 (9), 2601-2608.

(84) Thomas, J. L.; Tirrell, D. A. Acc. Chem. Res. 1992, 25 (8), 336342.

(85) Zhang, L.; Peng, T.; Cheng, S. X.; Zhuo, R. X. J. Phys. Chem. B 2004, 108 (23), 7763-7770.

(86) Carrion, C.; Domingo, J. C.; de Madariaga, M. A. Chem. Phys. Lipids 2001, 113 (1-2), 97-110.

(87) Takeuchi, H.; Kojima, H.; Yamamoto, H.; Kawashima, Y. J. Controlled Release 2001, 75 (1-2), 83-91.

(88) El-Sayed, M. E. H.; Hoffman, A. S.; Stayton, P. S. J. Controlled Release 2005, 101 (1-3), 47-58. 